\title{
HAMBURG KENTSEL DÖNÜŞÜM PROJELERİ: HAFENCITY VE WILHELMSBURG
}

\section{Cem ATAKARA}

\section{Özet}

$\mathrm{Bu}$ araştırma, Almanya'nın Hamburg kenti özelinde kent içerisinde kullanım dışı kalmış olan sanayi ve konut alanlarına odaklanan büyük ölçekli kentsel dönüşüm projelerinin planlama ve kentsel dönüşüm literatüründeki yerini, bu projelerin hazırlanış ve uygulanış biçimlerini incelemeye ayrıca ele alınan iki dönüşüm projesinin benzer ve farklı yönlerini karşılaştırmaya yönelik bir çalışmadır. Bu hedef doğrultusunda, öncelikle Almanya'nın idari yapısı, her eyaletin kendi bağımsız planlama süreci, Almanya'daki kentsel dönüşümün tarihsel süreci ve etkin aktörler alt başlıklar halinde incelenmiştir.

Hafencity Projesi, Hamburg kentinin kullanım dışı kalan eski liman alanının, kent merkezine katılması amacıyla hazırlanmış bir kentsel dönüşüm projesidir. Eski liman bölgelerinin dönüşüm sürecini aktarmak için seçilmiştir. Wilhelmsburg ise bu eski liman alanında çalışan işçi sınıfının, mahallenin konumunun limana yakın olması dolayısı ile konaklamayı seçtiği bir mahalledir. Mahalle son yıllarda yaşanan sel felaketi sonucu köhnemiş, sorunlu bir alan olmuştur. Bu yüzden bu iki birbiriyle yakın ve bağlantılı fakat kullanım açısından farklı alan (biri sanayi/liman diğeri konut/yerleşim alanı) kentsel dönüşüm konusunda incelenmek için seçilmiş̧ir. Araştırmanın yöntemi olarak Hamburg kentindeki iki dönüşüm projesi de yerinde incelenmiş, halka açık binalar, sosyal tesisler ve yapı fuarı ziyaret edilmiş ve insanların bölgeyi kullanım alışkanlıkları gözlemlenmiştir.

Anahtar Kelimeler: Kentsel Dönüşüm, Hamburg, Hafencity, Wilhelmsburg

\begin{abstract}
This research is a study to examine the place of large-scale urban transformation projects focusing on industrial and residential areas, which are out of use in the city, and the preparation and implementation of these projects.. In line with this goal, first of all, Germany's administrative structure, each state's own independent planning process, the historical process of transformation and active actors were examined under sub-titles.

The Hafencity Project is an urban transformation project designed to integrate the out-of-use old port area of the city of Hamburg into the city center. It has been chosen to convey the transformation process of the old port areas. Wilhelmsburg, on the other hand, is a neighborhood where the people working in this old port area chose to stay due to its location close to the port. The neighborhood has become an outdated and problematic area as a result of the flood disaster in recent years. Therefore, these two closely related but different areas in terms of usage (one industry/port and the other residential/settlement area) were chosen to be examined in terms of urban transformation. As the method of the research, two transformation projects in the city of Hamburg were examined on-site, public buildings, social facilities and exhibitions were visited, and people's usage habits of the area were observed.
\end{abstract}

Keywords: Urban Transformation, Hamburg, Hafencity, Wilhelmsburg 


\section{Giriş}

Kentlerde yaşanan sorunlara sadece fiziksel olarak değil ayrıca sosyal ve ekonomik olarak da çözümler üretmeye çalışan kentsel dönüşüm uygulamaları, bölge sakinlerinin gereksinimlerini karşılamaya yönelik sürdürülebilir adımlar atmak üzere tasarlanan projelerdir. Bu projelerin genel amacı, özellikle bölge sakinleri olmak üzere tüm kullanıcılara nitelikli, sağlıklı yapılar ve sosyal alanlar kazandırmaktır. $\mathrm{Bu}$ makalede iki kentsel dönüşüm teorisi etrafinda (yeniden geliştirme ve yeniden yapılandırma) Almanya'nın Hamburg kentindeki iki farklı kullanıma sahip bölgenin aynı dönüşüm aktörleri tarafından fakat iki farklı yaklaşımla nasıl bir değişim ve dönüşüme uğradıkları tartışılacaktır. Almanya özelinde 1900'lerin başından beri bu konunun ana aktörü olan “Uluslararası Yapı Sergileri (IBA-Internationale Bauausstellug / International Building Exhibition)" aslında bir yapı sergisinden çok, geleceğin kentleri için sürdürülebilir modeller öneren, toplumsal kültüre uygun mekanlar üreten bir kentsel gelişim vizyonu olarak tanımlanmaktadır. IBA, Hamburg eyaletinden aldığı yetkiyle de birçok kültürün birlikte yaşadığı kentte, nitelikli kentsel alanlar yaratmak, kentin merkezini genişletmek ve şekillendirmek, kenti kullanıcı odaklı planlamaya teşvik etmek üzere sürdürülebilir bir kent konsepti oluşturmuş, böylelikle halkın yaşam kalitesini arttırmayı hedeflemiştir.

Kentsel dönüşüm ile ilgili literatüre katkı sağlayacak olan bu çalışma, Almanya'daki örneklerle diğer ülke örneklerinin farklı bir karşılaştırmasını yapma imkanı tanımaktadır. Günümüzde kent merkezlerinin giderek büyümesiyle kent çeperlerinin de merkeze katılması kaçınılmaz olmuştur. Hamburg' daki iki köhnemiş ve fonksiyon kaybına uğramış kent çeperinin kent merkezine nası1 entregre edildiği sorusunun yanıtları aranmıştır.

\section{Almanya'nın İdari Yapısı ve Planlama Sistemi}

1990 yılında Doğu ve Batı Almanya'nın birleşmesiyle kurulan Federal Almanya Cumhuriyeti 16 özerk eyaletten meydana gelen federal bir devlet olarak varlığını sürdürmektedir. Almanya'nın bu federatif yapısında, yasamada merkez, yürütmede ise eyaletler güçlüdür. Yasama yetkisinin yanı sıra, eyaletler federal yasaları da kendi yetki ve sorumlulukları altında uygulayabilmektedirler. Almanya Federal Cumhuriyeti Anayasası, ayrıntılı bir yetki düzenlemesi ile hangi konuların federal devlet, hangi konuların ise eyaletler tarafından ele alınması gerektiğini belirlemektedir. Örneğin dış işleri, savunma, demiryolları ve posta hizmetlerine ilişkin yetkiler bütünüyle Federal Devlet'in sorumluluğu altındadır (Eraslan, 2007, p. 99). Almanya'da idari yapı, Federal Devlet, on altı tane eyalet, il yönetimleri, ilçeler ve belediyeler olmak üzere beş kademeden oluşmaktadır. Her eyalet, kendi yönetim biçimini ve mahalli idare birimlerini oluşturmaktadır. Bu durumun bir sonucu olarak da idari birimlerin yetki, sorumluluk ve görevleri bir eyaletten diğerine farklılıklar göstermektedir (Kayıkçı, 2003: 2). 


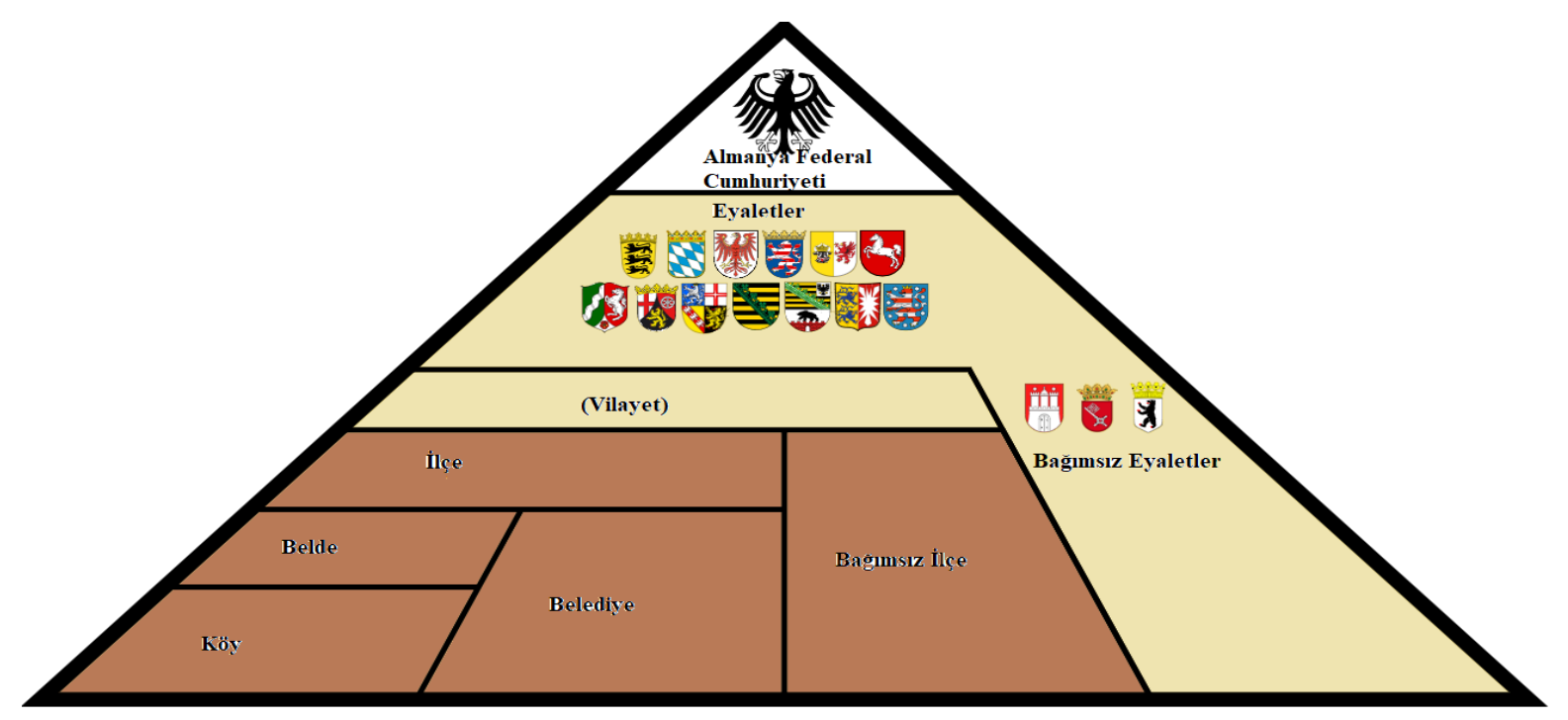

Şekil 1: Almanya'nın idari yapısı

(https://de.wikipedia.org/wiki/Datei:Administrative Gliederung_Deutschlands.svg\#/media/Datei:Administrative divisions_of_Germany.svg)

Almanya'daki planlama sistemi ise, ülkenin federalist yapısına uygun şekildedir. Buna göre Federal Hükümet, planlama için gerekli yasal çerçeveyi çizmekte ve eyaletler de bu çerçeveye uygun olarak (plan ve politikalar federal yapıyla uyumlu olmalıdır) kendi planlama yasalarını oluşturmakta ve uygulamaktadırlar. Ayrıca, tüm kamu planlama kurumlarının ve planların tasarlanmasının yatay ve dikey koordinasyonu, Alman planlama sisteminin önemli bir yanıdır. Almanya planlama sistemi incelendiği takdirde iki temel özellik karşımıza çıkmaktadır: Güçlü bir yasal çerçeve ve adem-i merkezileştirilmiş bir karar verme yapısı (Kayıkçı, 2003: 1).

Kendi planlama yasalarını yapan eyaletler arasında uygulama bazında karşıllaşılabilecek olası tutarsızlıkların önüne geçebilmek için Federal Bölge Planlama Yasası (Raumordnungsgesetz) adında bir çerçeve (çatı) düzenleme bulunmaktadır. Federal yasaların temel amacı, tüm ülkede eşit yaşam koşullarını sağlamaya çalışmaktır. Sistemin temel ilkesi, alt yönetimlere plan ve politikalarla ilgili uygulamalara ait ayrıntıların düzenlenmesi konusunda yetki vererek yerellik kavramını güçlü tutmak, aynı zamanda bu yönetimleri en üst düzeydeki yönetime (federal yapı) ait plana ve politikalara uygun hareket etmekle yükümlü kılmaktır (Kayıkçı, 2003: 3). Federal Bölge Planlama Yasası eyaletler için bir uygulama rehberi niteliğindedir. Eyaletler bu yasa çerçevesinde kendi mekan planlama yasalarını yaparak bölgesel politikalarını hazırlamaktadırlar.

Federal Bölge Planlama Yasası'nda açıklandığı üzere, federal hükümetin mekan planlama alanındaki görevi bölgesel eşitsizliği gidermek olarak tanımlanmıştır. Federal düzeyde de bu görev İçişleri, İmar ve Yurt Bakanlı̆̆ı'na (Bundesministerium des Innern, für Bau und Heimat) bağlı olarak çalışan Federal Imar ve Bölge Planlama Ofisi ((Das Bundesamt für Bauwesen und Raumordnung) tarafindan yürütülmektedir. Ofis, federal alanda bölgesel gelişme üzerine bir bilgi sistemi oluşturmakta ve devletin 
bölgesel gelişmesini sürekli olarak takip etmekte yorumlamakta ve değerlendirmektedir. $\mathrm{Bu}$ değerlendirmelerin ardından ise düzenli aralıklarla Alman Federal Meclisi'ne sunulmak üzere Federal Bakanlık'a rapor vermektedir (Eraslan, 2007: 119).

Federal İmar ve Bölge Planlama Ofisi ayrıca eyaletlerin ilgili bakanlıklarıyla ortak çalışma yürüterek bütün eyaletleri kapsayan ve çok genel stratejilerin belirlendiği bölge planları/bölgesel gelişme planları hazırlamaktadır. Ardından, her bir eyalet yönetimi, kendi sorumluluk alanındaki mekansal gelişmeyi, federal yönetim birimlerince hazırlanan yasal düzenlemelere ve federal yönetim ile eyaletlerin ilgili bakanlıklarının hazırlamış olduğu bölge planlarına bağlı kalmak koşuluyla kendisi belirlemektedir. Buna bağlı olarak; mekansal gelişme, eyaletten eyalete farkl1lık gösteren modellere göre ilerlemektedir (Eraslan, 2007: 116).

Tablo 1: Almanya Devlet kurumları ve görevleri.

\begin{tabular}{|l|ll|}
\hline Kurum & & \multicolumn{1}{c|}{ Görev } \\
\hline Federal Hükümet & $\bullet$ & Çerçeve (çatı) niteliğinde yasal düzenlemeler yapar. \\
\hline $\begin{array}{l}\text { İçişleri, İmar ve Yurt } \\
\text { Bakanlığı }\end{array}$ & $\bullet$ & Mekansal planlama, \\
& $\bullet$ & Federal anayolların ve demiryollarının bakımı, \\
& $\bullet$ & Eyaletleri, bölgesel planlar hakkında bilgilendirme. \\
\hline $\begin{array}{l}\text { İmar ve Bölge Planlama } \\
\text { Ofisi }\end{array}$ & $\bullet$ & Bilgi sistemi oluşturma, \\
\hline
\end{tabular}

\section{Almanya'da Kentsel Dönüşümün Tarihsel Süreci}

İkinci Dünya Savaşı'nı kaybeden Almanya'nın birçok kenti, savaştan kaçan sığınmacıların bu kentlere akın etmesi, endüstriyel tesislerin tahribatı, kent merkezlerinde ve konut alanlarında teknik altyapının çöküşü gibi durumlara sahne olmuştur. Özellikle bu sorunların yoğun olarak yaşandığı bölgelerde, ekonomik ve sosyal gelişim ve değişimleri kontrol etmek neredeyse imkansız bir hal almıştı.

Savaştan sonra Federal Almanya Cumhuriyeti, Marshall Planı aracılığıyla destek alarak Batı'ya entegre edildi. Diğer yandan Alman Demokratik Cumhuriyeti (DDR) maruz kaldığı kapsamlı tazminat yükleriyle birlikte Doğu Bloğuna entegre edildi. Yani Batı'da federal bir yapı ve Doğu'da merkezi bir yap1; Batı'da bir pazar ekonomisi ve Doğu'da planlı bir ekonomi vardı. Özel mülkiyet temelinde ve pazar ekonomisi çerçevesinde Batı Alman kentleri, birçok özel sektör veya kamu etkileşimi ile gelişmiş̧ir. Buna karşılık, ağırlıklı olarak kamulaştırılmış gayrimenkul ve planlı ekonomi koşullarında Doğu Almanya kentlerinin gelişimi, merkezi olarak kontrol edildi. Bu nedenle bu bölgedeki kentsel gelişimde mekansal öncelik kamu harcamasıyla gelişen endüstriyel alanlara tanınmıştır. 


\subsection{0’ler- Yeniden İnşa (Urban Reconstruction) Dönemi}

Savaş sonrası birçok Alman kentindeki endüstriyel tesislerin, altyapının, konut alanlarının ve kent merkezinin neredeyse tamamı yok edildi. Buna rağmen kentlere büyük mülteci akınları oldu. Bununla birlikte, her iki Alman devleti de aynı zorlukla karşı karşıya kaldı: Konut inşaatının hızlandırılması. Bu nedenle Federal Almanya Cumhuriyeti'nde yeniden inşa aşamasında 5 milyondan fazla daire inşa edildi. Çok sayıda Batı Almanya kentindeki eski binalar, kentin eski planlarına da uygun şekilde yeniden inşa edildi. Savaşın yarattığı tahribat yeni radikal bir başlangıç yapmak için bir firsat olarak kullanıldı. Tarihi kent merkezleri temelden yeniden tasarland1 (Strubelt, Gatzweiler, \& Kaltenbrunner, 2000: 45-48). Alman Demokratik Cumhuriyeti'nde ise Devlet Planlama Komisyonu kontrolünde toplu konutlar ikiden fazla çocuğu olan aileler veya kendi dairesi olmayan genç evli çiftler gibi sosyal aciliyet ve ulusal ekonomik öncelik kriterlerine uygun olan kesimlere tahsis edildi. Bu konutlar 4 veya 5 katlı apartman blokları şeklinde, genellikle 4000 ila 5000 sakine sadece yerleşim alanı teşkil edecek şekilde tasarlandı (Strubelt vd., 2000: 45-48).

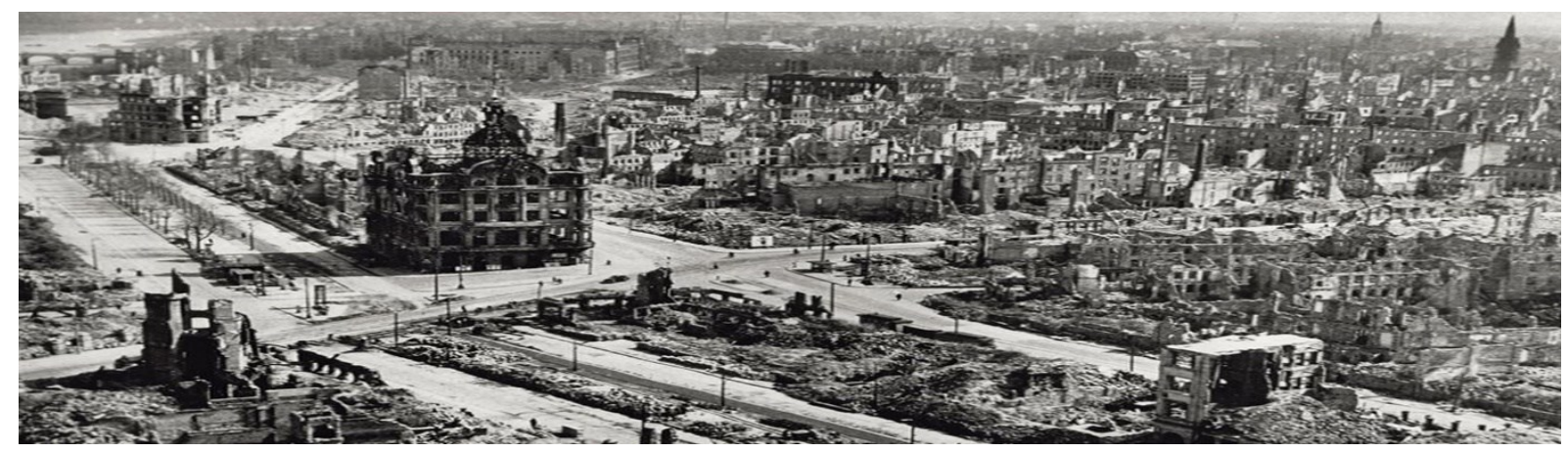

Resim 1: 2. Dünya Savaş1 sonrası Dressden merkezi. https://www.zeit.de/feature/zweiter-weltkrieg-dresdenrotterdam-warschau-drittes-reich-staedte-luftkrieg/seite-6; (c) Mondadori/Getty Images

\subsection{0'lar - Kentsel Genişleme/Yayılma (Urban Expansion) Dönemi}

Almanya Federal Cumhuriyeti'nde bu döneme "ekonomik mucize” adı verilir. Çünkü bu yıllarda batılı işgal kuvvetlerinin sağladığı ekonomik desteklerle birlikte büyük bir refah artışı olmuştur. Buna bağlı olarak nüfus artışı gerçekleşmiş, konut alanları da genişlemiş ve banliyöleşme başlamıştır. Ekonomik gelişim ile yeni endüstriyel alanlar inşa edilmiş ve var olanlar da genişletilmiştir. Bu gelişmelere bağl1 olarak ulaşım, eğitim ve sağlık hizmetlerinde iyileştirmeler yaşanmıştır (Strubelt vd., 2000: 48-49). Demokratik Alman Cumhuriyeti'nde ise artan ekonomik sıkıntılar ve endüstrileşmeyi birinci planda tutan politikalar sonucunda, konut alanlarında ihtiyaç duyulan ilerlemeler kaydedilmemiştir. Kentleri çevreleyen tarımsal alanları endüstri ve konut inşaatı ele geçirmiştir. Eski binalar yıkılarak yerlerine oldukça yüksek katlı binalar inşa edilmiştir. Konut alanları ile çalışma alanlarının belirgin bir şekilde ayrışmasıyla birlikte müstakil konutların yokluğunda inşa edilen çok katlı kiralık konutlar bu dönemin sembollerindendir (Strubelt vd., 2000: 48-49). 


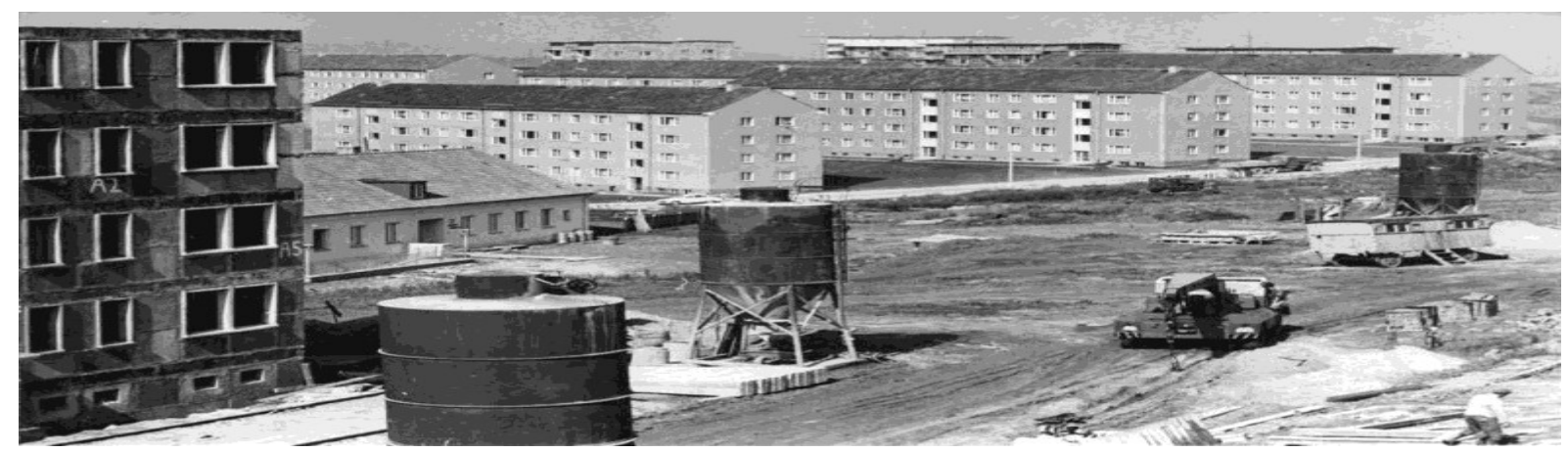

Resim 2: 1963 'te Doğu Almanya'da inşa edilen toplu konutlar

(https://www.bild.bundesarchiv.de/dba/de/search/?query=Bild+183-B0911-0012-001)

\subsection{0'ler- Kentsel Yenileme (Urban Renewal) Dönemi}

Ekonomik mucize dönemiyle önemli gelişmeler yaşayan Batı Almanya, 1970'li yıllardaki petrol krizi ile güçlü bir sarsıntı yaşamış, 1960'lardaki hızlı genişleme ve yayılma yavaşlamıştır. Bu dönemde yapılan yasal düzenlemelerle, tarihi kent merkezindeki eski dokuyu koruyarak yaşatan, mevcut konut stokunu modernleştiren, kültürel mirasa öncelik tanıyan ve bunları korumayı amaçlayan bir sistem oluşturulmuştur. Doğu'da ise, konut inşasının tarihteki en yoğun dönemi olmasına rağmen konut sorunu tamamen çözülememiş, kentsel kalite büyük ölçüde düşmüş ve kent merkezleri terk edilmeye başlanmıştır. $\mathrm{Bu}$ dönemde kent merkezlerindeki bu nüfus kaybının etkisiyle, merkezin yeniden canlandırılmasına ve günün her saati yaşayan, karma bir alan olmasına yönelik çalışmalar başlamıştır (Strubelt vd., 2000: 49-50).

\subsection{0'ler - Kentsel Yeniden İnşa (Urban Reconstruction) Dönemi}

Batı'da kentsel yeniden inşa konusunda odaklanılan ilk husus, eski binaların gerektiğinde tamamen korunarak gerektiğinde ise aslına sadık kalarak yeniden inşa edilmesi ve böylelikle kent merkezinin ve çeperinin tamamen yenilenmesi olmuştur. Bu vesile ile halkın, kent merkezine yeniden yönelmesi ve merkezde yüksek gelir sahibi grupların oluşturulması hedeflenmiştir. Doğu'da ise, yeni inşa edilen konutlarda tasarrufa gidilmesi konut kalitesinde düşüşe neden olmuştur. Birçok inşaat yarım kalmış veya yıkılmıştır. Yıkılan binaların yerine ise prefabrik binalar inşa edilerek konut sorununa çözüm aranması denenmiştir (Strubelt vd., 2000: 51-52).

\subsection{0'lar- Çok Yönlü Kentsel Kalkınma (Multi-Facetted Urban Development) Dönemi}

1990'ların başında Almanya'nın birleşmesi, tarihi açıdan oldukça önemli politik ve sosyal mücadelelere sahne olmuştur. Almanya'nın her iki tarafındaki yeni yaşam şartlarında denge sağlanması bir zorunluluk olmuş ve bu doğrultuda doğu kentlerindeki problemleri gidermek adına, yeni yasalar ve yaptırımlar uygulanmış, kentsel kalkınmanın sağlanabilmesi için yatırımcılara ciddi vergi teşvikleri sağlanmıştır (Strubelt vd., 2000: 53-54). 
İki Alman devletinin birleşmesi ile doğu kentlerindeki geniş̧ kırsal alanlar, düşük nüfus yoğunluğu, yetersiz altyapı ve sınırlı kamu taşımacılığından kaynaklanan bölgeler arasındaki ekonomik, sosyal ve ekolojik farklılıklar gün yüzüne çıkmıştır. Ülkenin doğusunu belli bir refah düzeyine çekme amacıyla yapılan düzenlemeler, Batı Almanya'da yer alan kimi eyalet yöneticileri tarafindan çoğu zaman sert bir dille eleştirilmiştir (Kayıkçı, 2003: 6).

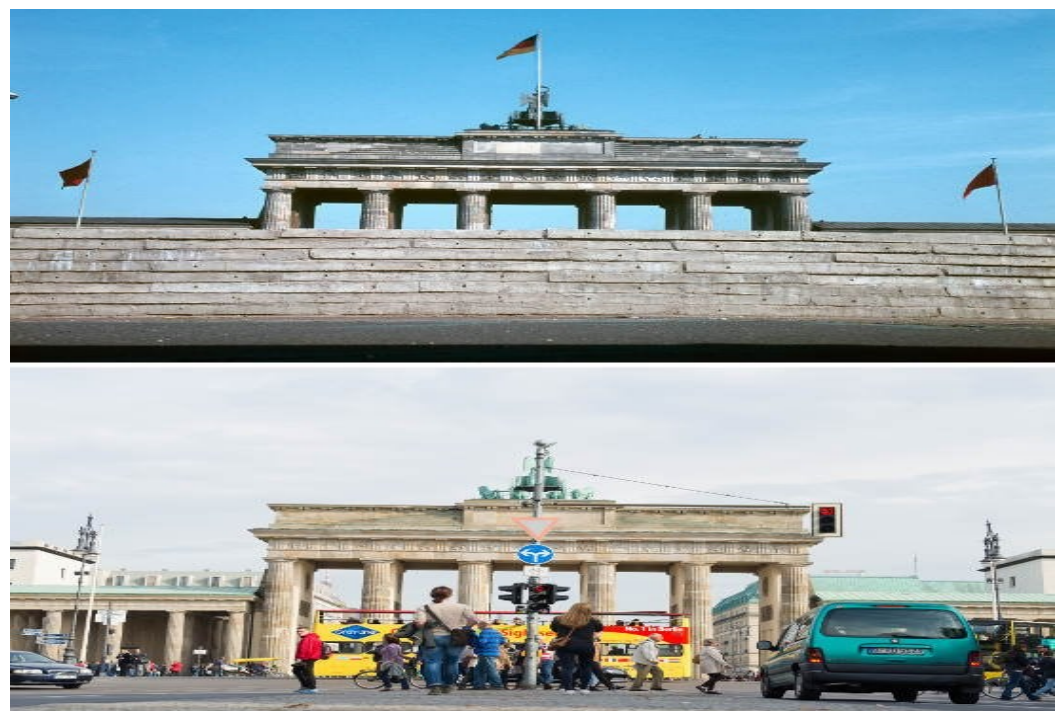

Resim 3: Brandenburg Kapısı, birleşmeden sonra. (https://www.thelocal.de/galleries/culture/photos-of-theberlin-wall-then-and-now-the-locall)

\subsection{0'ler- Kentsel Rönesans (Urban Renaissance) Dönemi}

2000'lere gelene kadar kent merkezlerinde yaşayan insan sayısı sürekli olarak gerilemekteydi. Kentsel Rönesans veya "kent merkezlerinin yeniden kesffi" gibi tanımlamalarla ifade edilen bu dönemde ise her şeyden önce yaşlı insanlar kente geri dönmüştür. Yaşamlarının bir dönemini çocuklarıyla birlikte banliyölerde geçiren bu insanlar, yaşamlarının yeni bölümünde ise kültürel faaliyetlere ve sağlık kurumlarına yakınlığa büyük önem vermeye başlamışlardır (Reicher, 2005: 59).

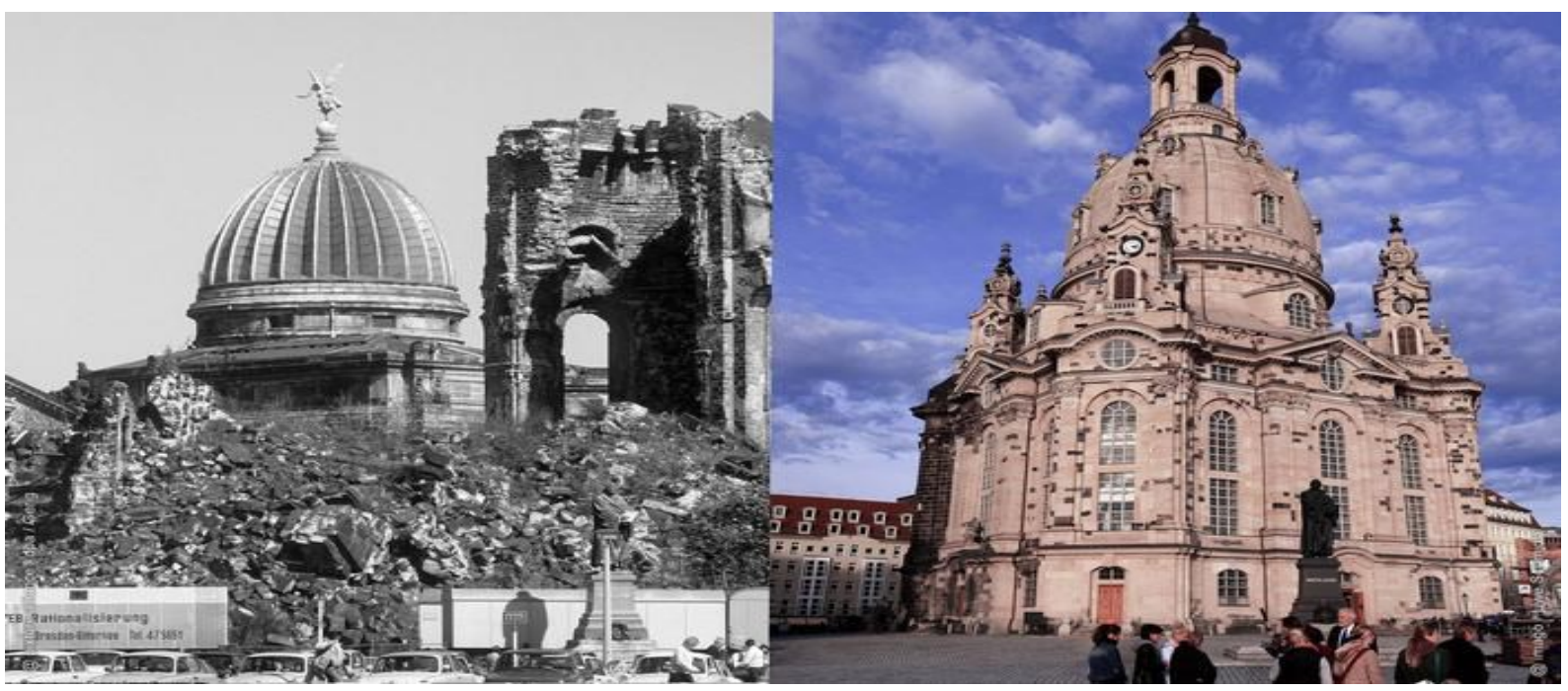


Resim 4: Frauenkirche (Dresden) 2005 yllında yeniden açıldl. (Https://www.dw.com/en/germany-beforeand-after-reunification/g-55082387)

Sanayileşmenin hızının durma derecesine gelmesiyle birlikte merkezlerde aktifleștirilmeyi bekleyen yeni alanlar oluşmuştur. Bununla birlikte kentin etrafındaki kırsal alanlar da kentin bir parçası olarak algılanmaya başlamıştır. Bu dönemde ayrıca İkinci Dünya Savaşı’ndan sonra yapılmış konutlarda önemli yenileme faaliyetlerinde bulunulmuştur (Reicher, 2005: 60). Bu dönemdeki dönüşüm faaliyetlerinin, bugüne kadar sürdürülen niceliğe yönelik uygulamaları bırakıp, kentsel yenilemede niteliğe (kaliteye) önem veren uygulamalar olduğu vurgulanmaktadır (Reicher, 2005: 56).

Ayrıca Ağustos 2001'de 2 milyar Euro'nun üzerinde bir bütçe ile var olan Kentsel Dönüşüm Batı programına ek "Kentsel Dönüşüm Doğu” programına karar verilmiştir. Bu programın uygulandığ1 kentlerde kentsel dönüşümün amac1, "ekonomik ve demografik yapısal değişimin üstesinden gelinmesi" ve "sürdürülebilir kentleşmenin sağlanması" olarak belirtilmiştir (Köktürk \& Köktürk, 2007: 11).

Kentsel Dönüşüm Doğu projesinde genel olarak dört ana eylem alanı belirlenmiştir. Bunlar: Konut varlığının ve kentsel imajın korunmasının amaçlandığı koruma bölgeleri (kentin kurulduğu bölgeler, tarihi anıtlar bölgesi), yeniden değerlendirme ve güçlendirmenin hedeflendiği yeniden yapılandırma bölgeleri (kısmen zarar görmüş ve yapısal olarak zayıf eski yapılanma bölgeleri), kapsamlı yıkımın ve boşalan alanların yeni yapılaşma veya dinlenme ve boş zaman kullanımına ayrılması planlanan yeniden geliştirme bölgeleri (henüz kısmen oturulan eski DDR büyük yerleşmeleri) ve son olarak kapsamlı yıkımla birlikte yeni yapılaşmanın hedeflenmediği yıkım bölgeleri (boş duran konutların olduğu DDR büyük yerleşim alanları) (Köktürk \& Köktürk, 2007: 12).

\section{Kentsel Dönüşüm: Hamburg}

Almanya'nın kuzeyinde ülkenin ikinci büyük eyaleti olan Hamburg, Kuzey Denizi’ne dökülen Elbe Nehri kıyısında yer alan bir liman kentidir. Almanya'nın en büyük, Avrupa'nın Rotterdam'dan sonra ikinci, dünyanın ise dokuzuncu büyük limanına sahip olan Hamburg kentinin tarihsel gelişimi ve önemi limanın işlevi oranında değişiklik göstermiştir. Ticaretin merkezi konumunda olan kent, bu sebeple tarih boyunca pek çok saldırıya ve bu saldırıların yol açtığı yıkımlara sahne olmuştur. 19. yüzyıl sonunda "Yenidünya'ya" yapılan seferlerden dolayı denizcilik sektörü Hamburg'da en etkili sektör olmuş ve Hamburg- Amerika hattı dünyanın en büyük transatlantik denizcilik rotası durumuna gelmiştir. $\mathrm{Bu}$ yüzden Hamburg'a “Avrupa'nın Yenidünya'ya açılan kapısı" denilmektedir (Akyol, 2010: 29) . 
1842 'deki büyük yangının etkilerine ek olarak iki dünya savaşı sırasında yaşanan bombardımanlar kentin mimari mirasını yok etmiş̧tir. Sonrasında da etkileri oldukça sert hissedilen soğuk savaş döneminde, bölünen Almanya'dan yalnızca 50 km. uzaklıktaki, Doğu Almanya ve Baltık ülkeleriyle ilişkisi kesilmiş olan Hamburg, ekonomik olarak gerilemiş olsa da 1990'da Almanya'nın birleşmesinden sonra tekrar eski önemli konumunu almıştır (Akyol, 2010: 29).

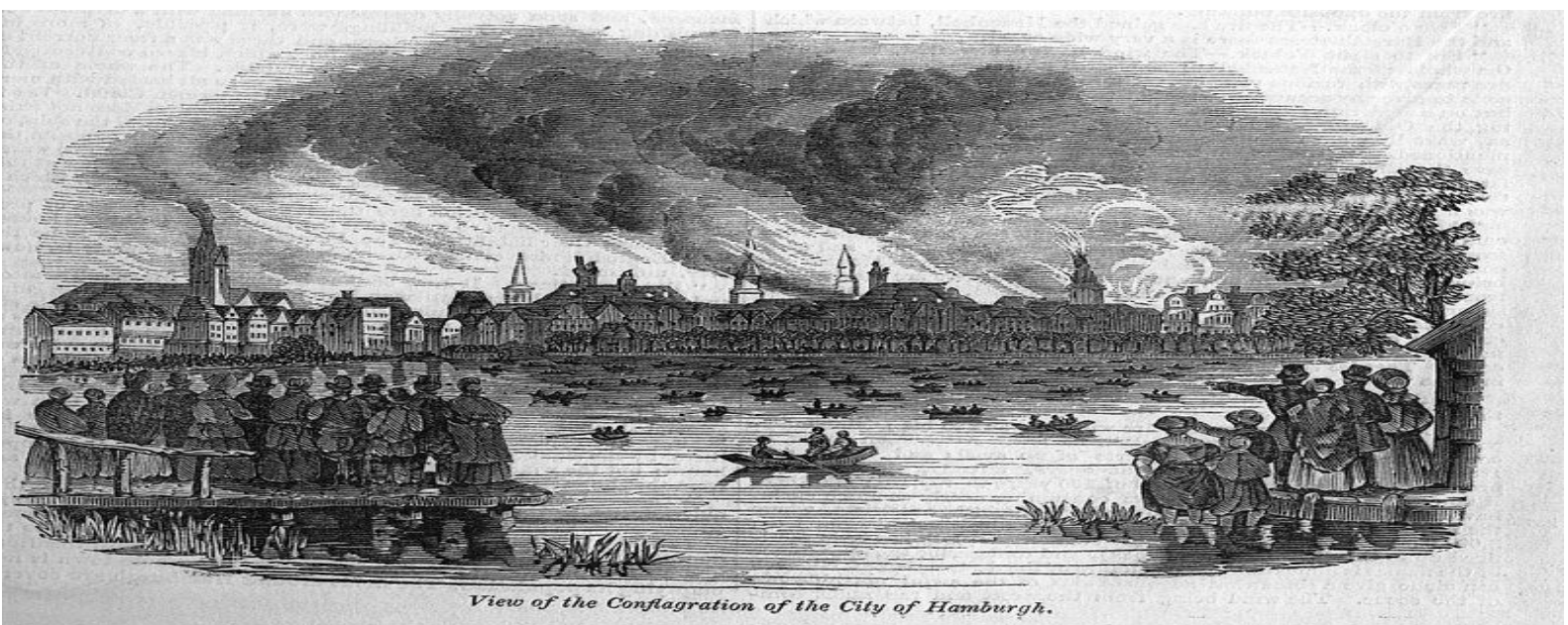

Resim 5: 1842 Hamburg Yangını (The Illustrated London News. Vol. 1. From May 14 to December 31, 1842)

Hamburg kentinin yaşadığı dönüşümler planlı ve plansız olarak ikiye ayrılabilir. Plansız olanlar büyük yangın ve iki dünya savaşı sonrası yaşanan yıkımdır. İlk planlı dönüşüm ise 19. yüzyılın sonlarında, liman bölgesini genişletmek, ticari bir depo bölgesi yaratmak, doğrudan sudan karaya modern aktarma yapabilmek ve daha etkin bir ulaşım ağına sahip olmak adına eski limanın yanındaki mahallelerin yıkılıp yirmi binden fazla kişinin tahliyesiyle sonuçlanan bir özel liman bölgesi yaratmaktı (Bruns-Berentelg, 2014: 2).

21. yüzyıla gelindiğinde, kentlerin genişlemesi, kentin kullanımı ve kent alanlarının günümüz ihtiyaçlarına cevap verebilmesine yönelik, kentlerin yeniden kurgulanması gerekliliği doğmuştur. Hamburg'da da hizmet ve bilişim sektörlerinin ön plana çıkması, denizcilik sektörünün kentten ayrılmadan daha uzak bölgelere taşınması, endüstriyel alanların boşalması ve arada kalan bölgelerin de köhnemeye başlamasıyla kentin bu bölgelerini kapsayan dönüşüm çalışmaları planlanmaya başlamıştır. $\mathrm{Bu}$ değişime cevap verebilmesi amacıyla eski liman bölgesi (Hafencity) ve daha çok buradaki liman işçilerinin konakladığı Wilhelmsburg mahallesinin dönüşüm projeleri, Hamburg'daki iki önemli kentsel dönüşüm projesidir.

\subsection{Kentsel Dönüşümün Ana Aktörü: IBA (Internationale Bauausstellung)}

IBA, 100 yıldan beri faal olan Uluslararası İmar Fuarı'nı simgelemekte ve bilinen bir fuardan çok daha fazlasını içermektedir. Burada sergilenen sadece binalar değildir, daha çok, tıpkı bir laboratuvarda olduğu gibi, canlı olarak araştırma ve geliştirme faaliyetleri gerçekleşmektedir. Tek fark, burada laboratuvarın kentin kendisinden ibaret olup, araştırma 
neticelerinin imar yoluyla gerçekleştirilecek olmasıdır (IBA Hamburg,https://www.internationalebauausstellung-hamburg.de/en/story/iba-hamburg.html).

IBA Hamburg, Hamburg Belediyesi tarafından kurulmuştur. Dolayısıyla maliyeti de Belediye tarafindan üstlenilmektedir. Fakat projeler ayrıca finanse edilmektedir. Bu finansman genelde IBA Hamburg'un başından itibaren birlikte çalıştığı yatırımcılar tarafından sağlanmaktadır.

Hamburg Belediyesi tarafından kurulan ve çalışanları arasına semt sakinlerinin ve yatırımcıların da dahil olduğu bu özerk şirket, projeler planlayıp yarışmalar düzenlemekte ve geliştirilen bu projelerin uygulanması ve koordinasyonunu sağlamaktadır.

Geliştirilen projelerin ana teması, hızla büyüyen ve büyümenin de devam ettiği Hamburg gibi bir kentte, var olan çok sayılı ve tezat gibi görünen konuların birbirleriyle uyumlu hale getirilmesidir. Büyürken de iklimi korumak, göçmenleri entegre etmek, ama aynı zamanda kültürlerin çeşitliliğini muhafaza ederek kenti yeniden yapılandırmak ve alanlardan tasarruf etmek ana temaya dahil edilmektedir (IBA Hamburg, https://www.internationale-bauausstellung-hamburg.de/en/story/ibahamburg.html).

\subsubsection{IBA’nın Kentsel Dönüşüm Proje Aşamaları}

Bir dönüşüm projesi belirlenirken katılımın birinci planda tutulduğu, altı ayrı ama birbiriyle bağlantılı aşama tasarlanmaktadır. Proje geliştirme yolunda ilk adım olarak bir fizibilite çalışması yürütülmektedir. Fizibilite çalışmasının amacı, proje hakkında daha fazla karar vermek için sağlam bir temel olarak, gerekli zaman planlaması ile doğru bir maliyetlendirme ve finans planı oluşturmaktır.

İkinci aşama rekabet/yarışma aşamasıdır. Bu aşamada yapılan, uzman kurumlarla yerel paydaşlar arasında bir fikir birliğine varma arayışıdır. IBA Hamburg, çalışmalarında mümkün olan en büyük şeffaflı̆̆ hedeflemektedir. Faaliyetler konut sakinleri ve dernekler gibi kilit paydaşlara açılarak, ihtiyaçlarının erken bir aşamada dikkate alınması sağlanmaktadır.

Üçüncü aşama fonksiyon planıdır. Plan, konut birimlerini, arsa bölümünü, yolları, araç erişimini ve otopark alanlarını gösterir. IBA Hamburg söz konusu olduğunda, fonksiyon planı tüm aşamalarda önemli bir etkiye sahip olduğu için proje geliştirme süreci boyunca hayati bir araçtır. Dolayısıyla, fonksiyon planlama sürecinin sonuçları maliyet ve finans planlamasının temelini oluşturur. Dahası hem basın hem de halkla ilişkiler, pazarlama amaçları ve bireysel mülklerin tanıtımı için kullanılabilecek önemli bir iletişim aracıdır. Bu nedenle, fonksiyon planı zaman içinde belirli bir nokta ile sınırlı olmaktan ziyade, sürekli gözden geçirme ve geliştirme süreci boyunca olası ayarlamalara tabidir.

Dördüncü aşama yasal çalışmalardır. Fonksiyon planının hazırlanmasından sonra planların yapı mevzuatına göre düzenlenmesi, yönetmeliklerine uygun bir arazi kullanım planına hazırlanmasıdır.

Beşinci aşama altyapı aşamasıdır. Sokaklar, köprüler, tüneller, meydanlar, parklar ve spor tesisleri, ilgili bölge makamlarıyla yakın koordinasyon içinde IBA Hamburg yönetiminde oluşturulmaktadır. 
Son aşama pazarlama aşamasıdır. İhale prosedürleri, tüm müşterilere danışmanlık ve satın alma sözleşmesinin imzalanması aşamasıdır. İletişim ve pazarlama; yayınlar, etkinlikler ve fuarlar, reklamcılık ve yüz yüze iletişim hedef gruplara hitap etmek için kullanılmaktadır (Hansing, 2017: 9).

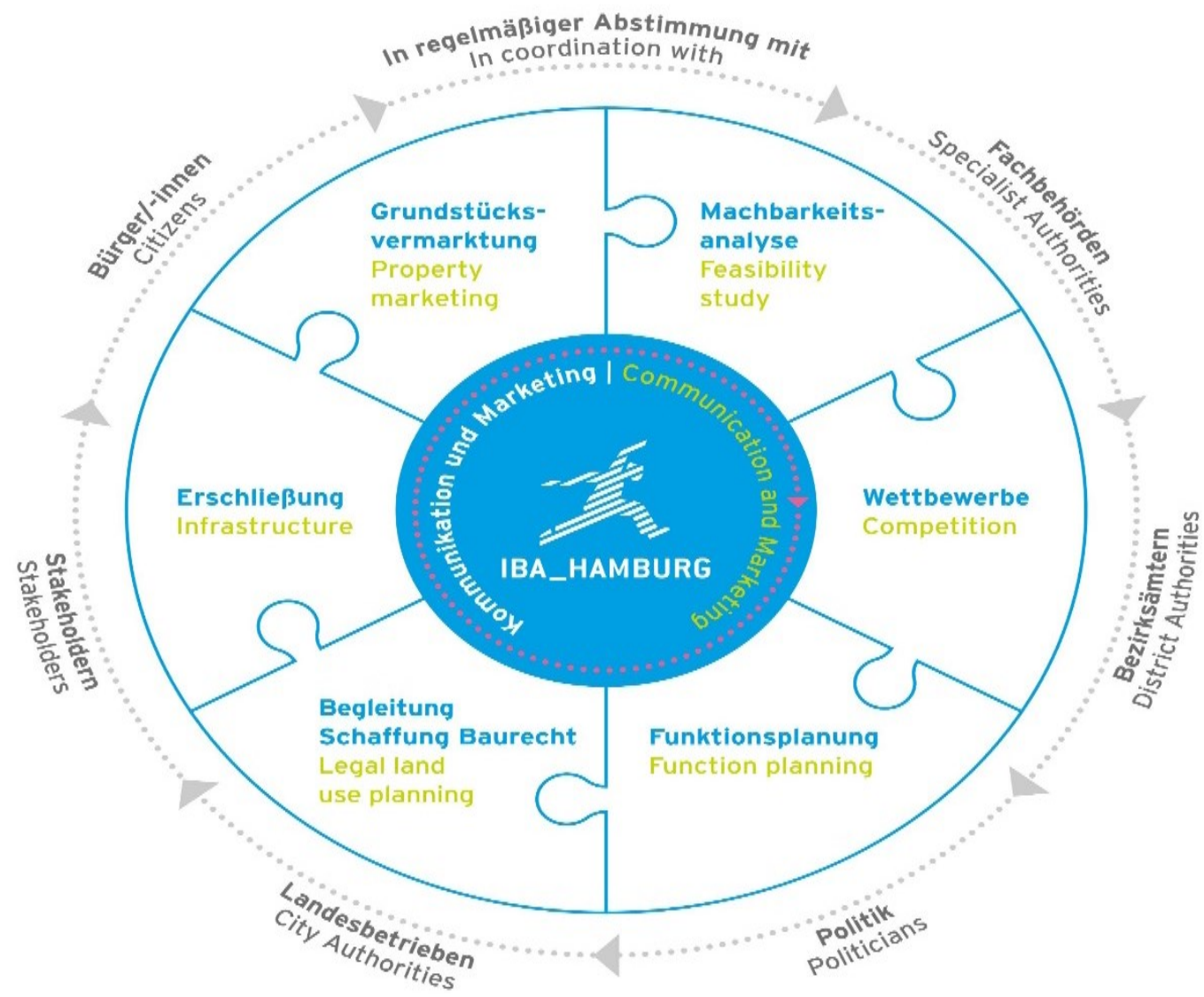

Şekil 2: Proje Geliştirme Aşamaları (Hansing, 2017: 9).

\subsection{Hafencity Kentsel Dönüşüm Alanı}

Avrupa'nın en eski liman alanına sahip olan Hamburg'da kent merkezinin gelişmesiyle birlikte liman alanı artık kentin içinde kalmıştır. Bundan dolayı, Hafencity dönüşüm projesi, merkeze yakın eski liman bölgesini yenileyerek kente entegre edip, kent merkezini genişletmeyi hedeflemiştir. Planın bir diğer ana hedefi, dönüşüm projesinin Hamburg'un ekonomik, ekolojik sosyal ve kültürel gelişimine katkıda bulunmasını sağlamaktır. Projenin öne çıkan işlevi, kent merkezine hakim olan konut alanlarının karma kullanımını sürdürerek, ticaret, eğitim, kültür eğlence ve turizm alanlarında yeni iş ve firsatlar yaratmaktır. 


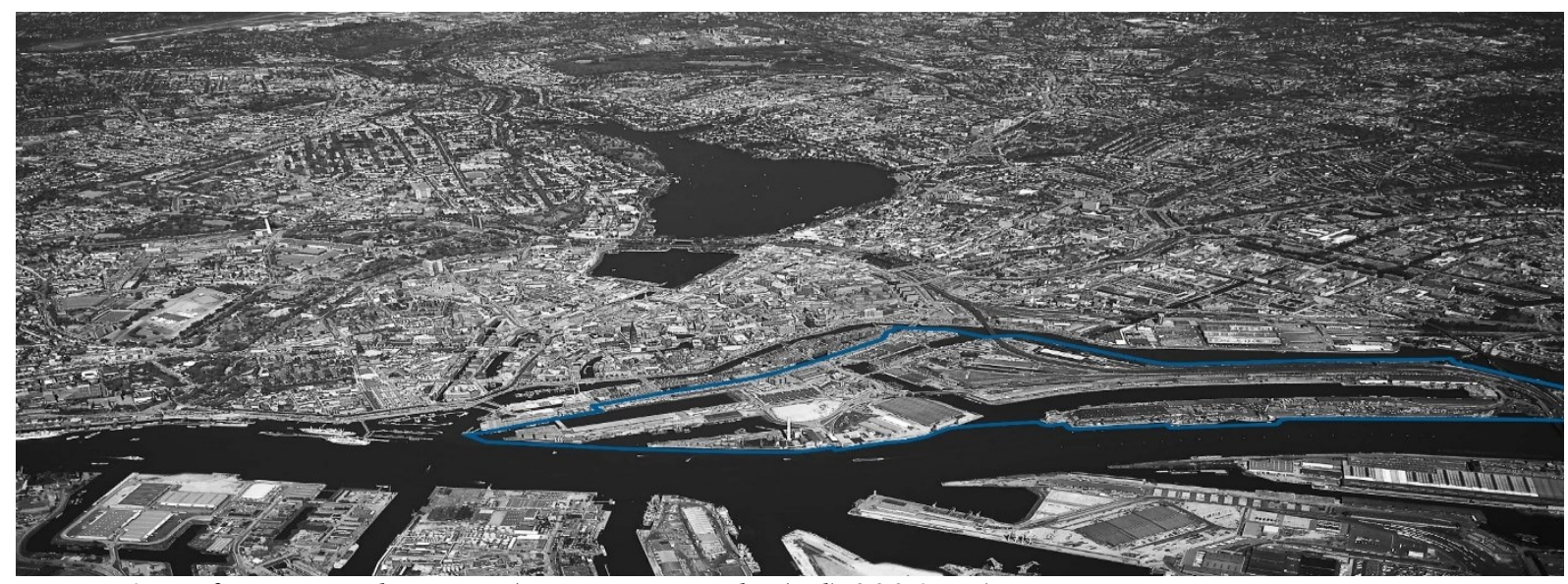

Resim 6: Hafencity'nin konumu (Bruns-Berentelg (Ed) 2006.jpg)

1997'de dönemin belediye başkanı Henning Voscherau tarafından duyurulan proje aynı yıl senato ve parlamentodan da geçerek 1999 yılında yarışmaya açılmıştır. 2000 yılında çalışmalara başlanılmış ve 2003 'te ilk bina tamamlanarak 2005 yılında ise ilk sakinler bölgeye taşınmıştır (Bruns-Berentelg, 2014: 2).

Limanın su ile doğrudan ilişkisinden dolayı ilk başta alanın taşkınlardan korunması için yükseltilmesi gerekiyordu. Bu yüzden deniz seviyesi beş metreden sekiz metreye yükseltildi. Bu müdahale çok sayıda eski, alçak binanın entegrasyonunu zorlaştırdı ve geciktirdi (Bruns-Berentelg, 2014: 3). Bu işlem sırasında limanın tarihi duvarları ve işlemeleri korunmuş, ayrıca bölgedeki mevcut binaların siluetinin bozulmaması amacıyla, bu yapıların görünümünü kapatacak yükseklikteki yeni yapılara izin verilmemiştir (Akyol, 2010: 40).

2000 yılında açıklanan master planda, 20.000 ofis ve 5.500 konut olması düşünülüyordu. Fakat 2006'da revize edilen plan, 45.000 ofis ve 7.000 konut sayıs ile 15.000 bölge sakinini hedefliyordu (BrunsBerentelg, 2006: 55). 


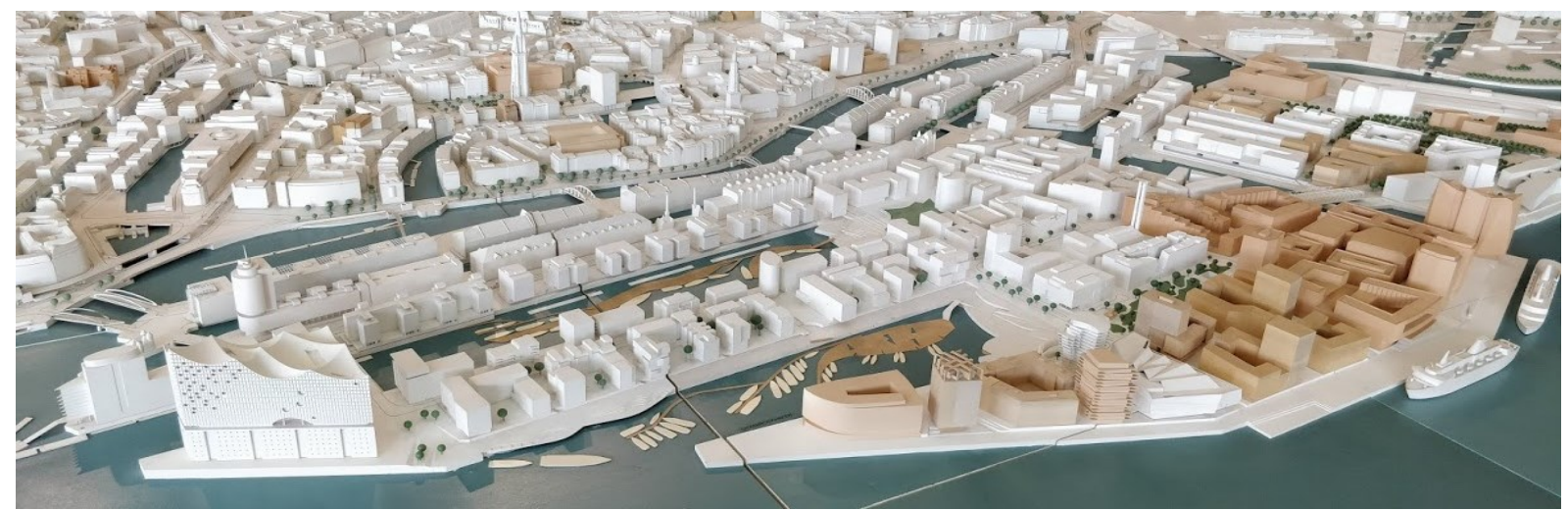

Resim 7: Hafencity proje alanı (yazarın kendi arşivi, Şubat 2020)

Hafencity projesinde, yaya yollarını \% 70'i araç yolundan ayrılmış şekilde tasarlanmış ve yaya ulaşımı köprülerle sağlanmıştır. Isıtma sistemleri ise yenilikçi ve sürdürülebilir bir konseptte düşünülmüş, doğalgazla ısınan binalara oranla \% 27 oranında daha az karbon emisyonu yaratacak olan termal enerjili 1sıtma sistemleri kullanılmıştır (Akyol, 2010: 40).

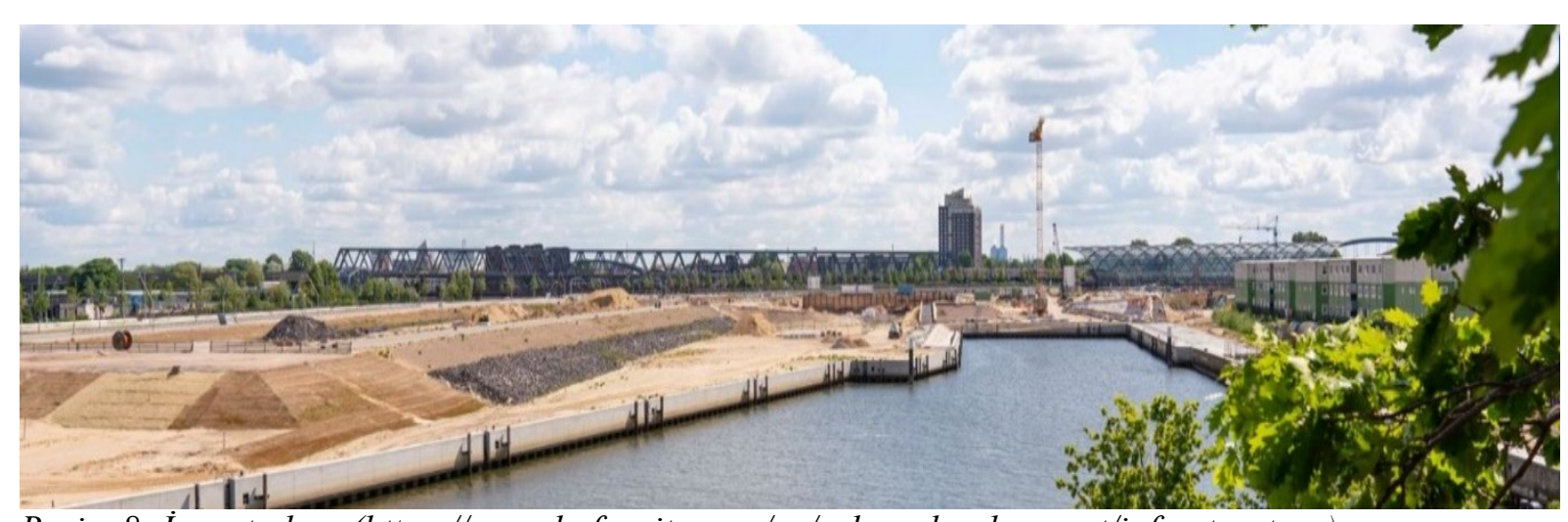

Resim 8: Inşaat alanı (https://www.hafencity.com/en/urban-development/infrastructure)

Hafencity projesinde en önemli görülen yapı ise Elbe Filarmoni Konser Salonu'dur. İlk master planında yer almamasına rağmen, alanda anıtsal bir yapının gerektiği düşünülmüş ve yenilenen plana eklenmiştir. Bölgenin kültürel merkezi olması istenilen salon, eski ambar binası temel alınarak tasarlanmıştır. Daha tamamlanmadan kendisine ayrılan bütçeyi aşan salonun inşaatı 2017 yılında tamamlanmıştır (Akyol, 2010: 44).

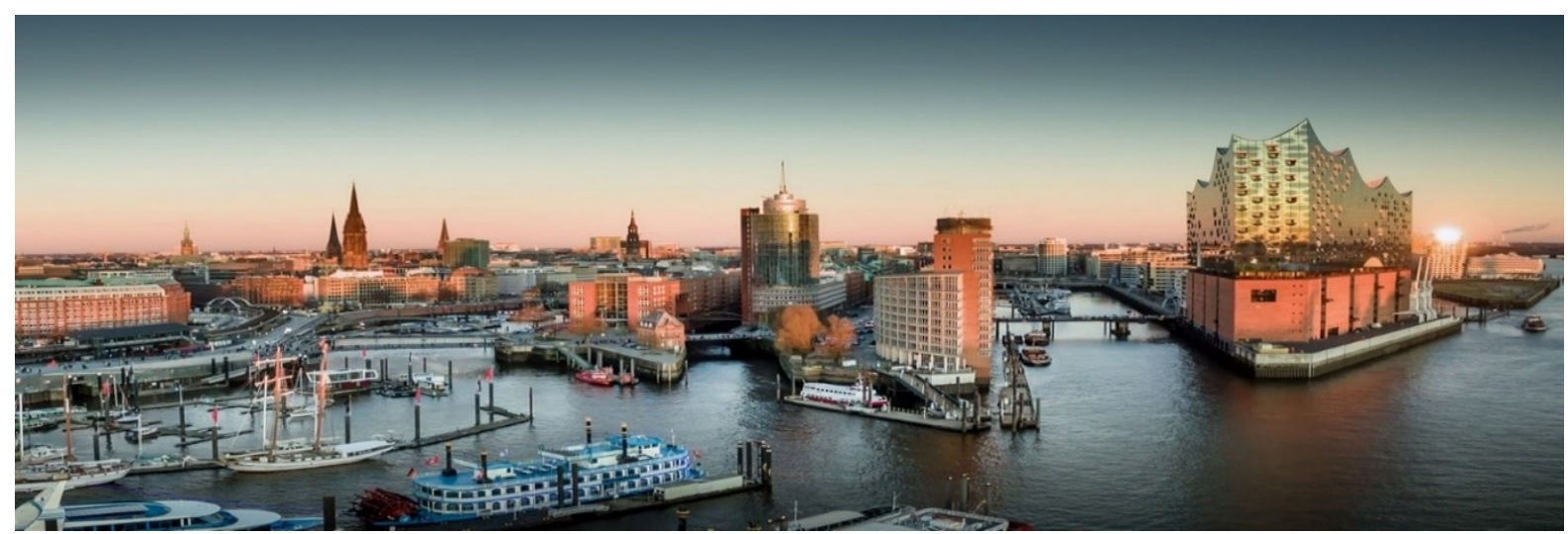

Resim 9: Sağda Filarmoni salonu. (https://www.hafencity.com/en/overview/about-hafencity) 
Projenin finansmanını sağlamak adına, bölge arazisinin büyük bir kısmının kamu mülkiyetinde olmasından dolayı buradaki parsellerin özel sektöre satışıyla yaklaşık 10 milyar Euro gelir elde edilmiş, buna ek olarak da 3 milyar Euro kamu yatırımı olmuştur. Almanya'nın lider medya kurumlarından biri olan Der Spiegel, uluslararası tüketim malları grubu Unilever, denizcilik şirketi Germanischer Lloyd gibi binden fazla çalışanı olan şirketler bölgeden arazi alıp taşınmıştır. Bunların yanı sıra Hafencity Üniversitesi ile Uluslararası Hamburg Denizcilik Müzesi de bu bölgededir (Bruns-Berentelg, 2014: 4). Hafencity her ne kadar son derece iyi planlanmış, programlanmış ve uygulamaya konulmuş bir proje gibi görünse de eleştiriler de bulunmaktadır. Projede özellikle katılım boyutunun eksikliği kentte dönüşümün kendilerine sorulmadan gerçekleştirildiğini savunan, sanatçllar ve müzisyenlerden oluşan bir grup tarafından dile getirilmiştir. Ayrıca bölgedeki soylulaştırmaya da karşı çıkan grup, tüm mali kaynakların Filarmoni Salonu gibi projelere aktarıldığını ve eğitim, sağlık gibi sosyal alanlarda kısıtlamalara gidildiğini, dar gelirlilerle yoksulların kaderine terkedildiğini söyleyen bir manifesto yayınlamışlardır (Deutschlandfunk Kultur, 2010; WELT, 2009).

Hafencity bugün Avrupa'nın en büyük şehir içi kentsel dönüşüm alanını oluşturmaktadır. Birkaç yıl öncesinde ham bir liman ortamı olmaktan çıkıp çeşitli sosyal kültürel ve siyasi gelişim potansiyeline sahip bir kentsel alana dönüşmüştür. Diğer kentsel gelişim projelerinden farklı olarak, Hafencity’nin kapsadığı alanda neredeyse hiç sakin yoktu. Kent içindeki komşu bölgeler de çok az konut içeriyordu. 2021 itibariyle burada 3.000 hanede 6.000 civarında insan yaşamaktadır. 750 şirkette 15 bin kişi çalışmaktadır. Bölge tamamlandığında, burada 15 bin kişi yaşayacak ve 45 bin kişi de burada çalışma alanları edinecektir. Çocuklu ailelerin oranı da dikkate değerdir. \%22,6'lık oranla Hamburg ortalaması olan \%18'in oldukça üzerindedir (hafencity.com/en/urban-development/social-development, 03.12.2021). Bu da çocuklu ailelerin yeniden kent merkezleri ve kent çeperlerinde yaşadığının ve 1960'lardaki banliyöleșme akımının tersine dönmeye başladığının göstergesidir. Uzun bir süre kent içinde yaşamak çok çekici görünmüyordu. Ancak günümüzde kent içi yaşam, insanların okula, işe alışveriş veya eğlence alanlarına kısa mesafelerle vardığı sürdürülebilir bir yaşam modelini mümkün kılıyor. Bu durum birçok kişi için zamandan tasarruf anlamına gelmektedir. Aile arkadaşlar ve istihdam olanaklarını daha kolay birleştirebiliyorlar.

Birçok popüler kent içi bölgenin aksine, Hafencity 'de tek kişilik haneler hakim değildir. Bunun yerine, ailelerin ve öğrencilerin bir karışımı vardır. Hafencity' deki ortalama hane 2,1 kişiden oluşmaktadır. Eimsbüttel, St Pauli, Neustadt veya St Georg gibi diğer popüler Hamburg mahallelerinde bu rakam 1.5'tir (hafencity.com/en/urban-development/social-development, 03.12.2021).

Hafencity`de gündelik yaşam oldukça canlı ve halka açık alanlar çok çeşitli insan gruplarıyla ve günün farklı saatlerinde kullanımlarla tanımlanmaktadır. Bu kullanıcılar, kent sakinleri ve çalışanlarının yanı sıra, çoğunlukla dünyanın dört bir yanından ve Almanya'nın her köşesinden öğrenciler ve ziyaretçilerdir. Hamburg'dan birçok kişi Hafencity'yi keşfedip cazip kültür ve eğlence tesislerini kullanmaktadırlar. Meydanlar, parklar ve gezinti yerleri, çeşitli grupların taleplerini karşılayan buluşma yerleridir. $\mathrm{Bu}$ 
kamusal alanların bölgedeki varlığı birbirleriyle çok az temas halinde olan nüfus grupları arasındaki tesadüfi buluşmaları teşvik etmekte ve böylece mahalleler içinde etkileşimi artırmak için bir araç sağlamaktadır.

Diğer birçok sahil projesiyle (Londra'daki Canary Wharf gibi) karşılaştırıldığında, Hafencity tamamen ticari bir yer olarak canlandırılmamıştır. Bunun yerine bölge, iş, konut, eğitim, kültür eğlence, turizm ve perakendecilik gibi birçok kullanımın olduğu karma bir yapıya sahiptir. Tüm bu veriler bize Hafencity'nin kentsel dönüşüm teorilerinden yeniden canlandırmaya daha uygun olduğunu göstermektedir. Yeniden Canlandırma; "sosyo-kültürel, ekonomik ya da fiziksel açılardan bir çöküntü süreci yaşamakta olan kentsel alan parçalarının, çöküntüye neden olan faktörlerin ortadan kaldırılması ya da değiştirilmesi sonucu, o alanın tekrar hayata döndürülmesi, canlandırılması", (Karadağ, 2008) yöntemine verilen isimdir. Yeniden canlandırılan bölgeler sadece fiziksel değil ekonomik olarak da gelişmektedir. Bu ekonomik gelişimin varlığı da fiziksel yapının daha uzun süre korunabilmesine olanak sağlayacaktır. Aksi taktirde bölgede yeniden köhneme ve eskime görülebilir.

Tablo 2: Sayılarla Hafencity Projesi

\begin{tabular}{|l|l|}
\hline \multicolumn{2}{|c|}{ Sayılarla Hafencity Projesi } \\
\hline Amaç & $\begin{array}{l}\text { Konut, ofis, kültür, turizm ve alışveriş için liman } \\
\text { ortamına sahip yeni sahil kent merkezi }\end{array}$ \\
\hline Alanın toplam büyüklüğü & 155 hektar \\
\hline Su alanı & 55 hektar \\
\hline Arazi alanı & 100 hektar \\
\hline Net inşaat alanı & 60 hektar \\
\hline Konut sayısı & $10.000-15.000$ kişi için 5.500 konut \\
\hline Ofis sayısı & 45.000 kişi için ofis alanı \\
\hline Belediye binasına uzaklık & $2.5 \mathrm{~km}$ \\
\hline Merkez tren garına uzaklık & 3 km \\
\hline Havaalanına uzaklık & 13 km \\
\hline Ulaşım & $\begin{array}{l}\text { Kent merkezine ve otoyollara bağlantıları olan } \\
\text { verimli yol ağı ve toplu taşıma sistemi }\end{array}$ \\
\hline Hamburg nüfusu & 1.8 Milyon \\
\hline Bütçe & $\begin{array}{l}10 \text { milyar Euro özel + 3 milyar Euro kamu } \\
\text { yatırımı }\end{array}$ \\
\hline Süreç & 3.070 konut ve 80 proje tamamlandı; yapım \\
\hline
\end{tabular}




\subsection{Wilhelmsburg Mahallesi Dönüşüm Alanı}

Hamburg'un merkezinde yer alan Wilhelmsburg bir nehir adasıdır ve alan açısından Hamburg'un en büyük bölgesidir (Avlar \& Yılmaz, 2018: 109). 1962'deki büyük firtına ve taşkın, bölgede yüzlerce insanın can kaybına neden olmuştur. Bir çok bölge sakini de bu olaydan sonra bölgeden ayrılmıştır (Hellweg, 2018: 116). Tarihsel olarak hep işçi sınıfı mahallesi olan Wilhelmsburg 'ta tersanelerde, fabrikalarda ve demiryollarında çalışan insanlar yaşamıştır. Bu insanların \%34'ünü de göç geçmişi olan kişiler oluşturur (Chamberlain, 2020: 2). Göçmen ve işçi sınıfi mahallesi olan Wilhelmsburg hep bir sorun alanı olarak görülmüş kentin geri kalanından ayrılmış ve konut gelişimi için uygun bir yer olarak düşünülmemiştir

(Hellweg, 2018: 117).

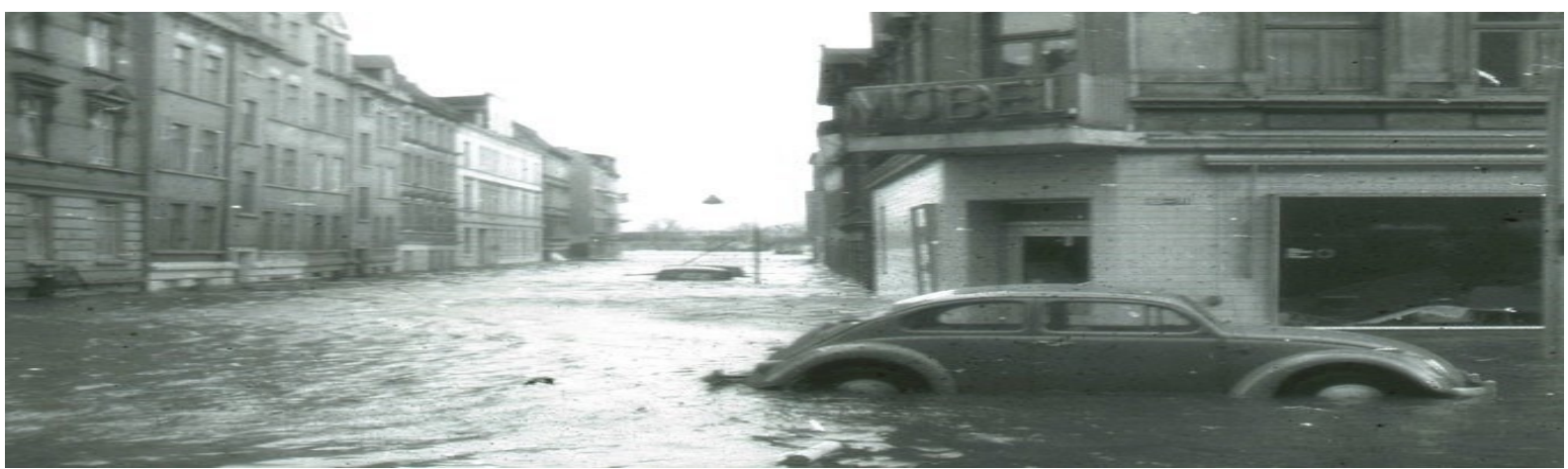

Resim 10: 1962 büyük taşkını sırasında Wilhelmsburg mahallesi (https://hamburg.mitvergnuegen.com/2019/vergnuegteviertel-damals-und-heute-wilhelmsburg/)

Wilhelmsburg sakinleri, çocuklar ve gençler için daha iyi okullar, kaliteli konutlar ve yeni umutlar için 2001 yılında Hamburg yetkililerinin dikkatini çekmek adına "Wilhemsburg İçin Gelecek Konferansı" düzenlemişlerdir. Yüzden fazla vatandaşın Hamburg yetkilileri ile bölge için yeni bir vizyon oluşturmak adına yaptığı çalışmaların sonucunda IBA dönüşüm projesini tamamlamak amacıyla bölgeye yaklaşık 700 milyon Euro yatırım çekmiştir (Hellweg, 2018: 116).

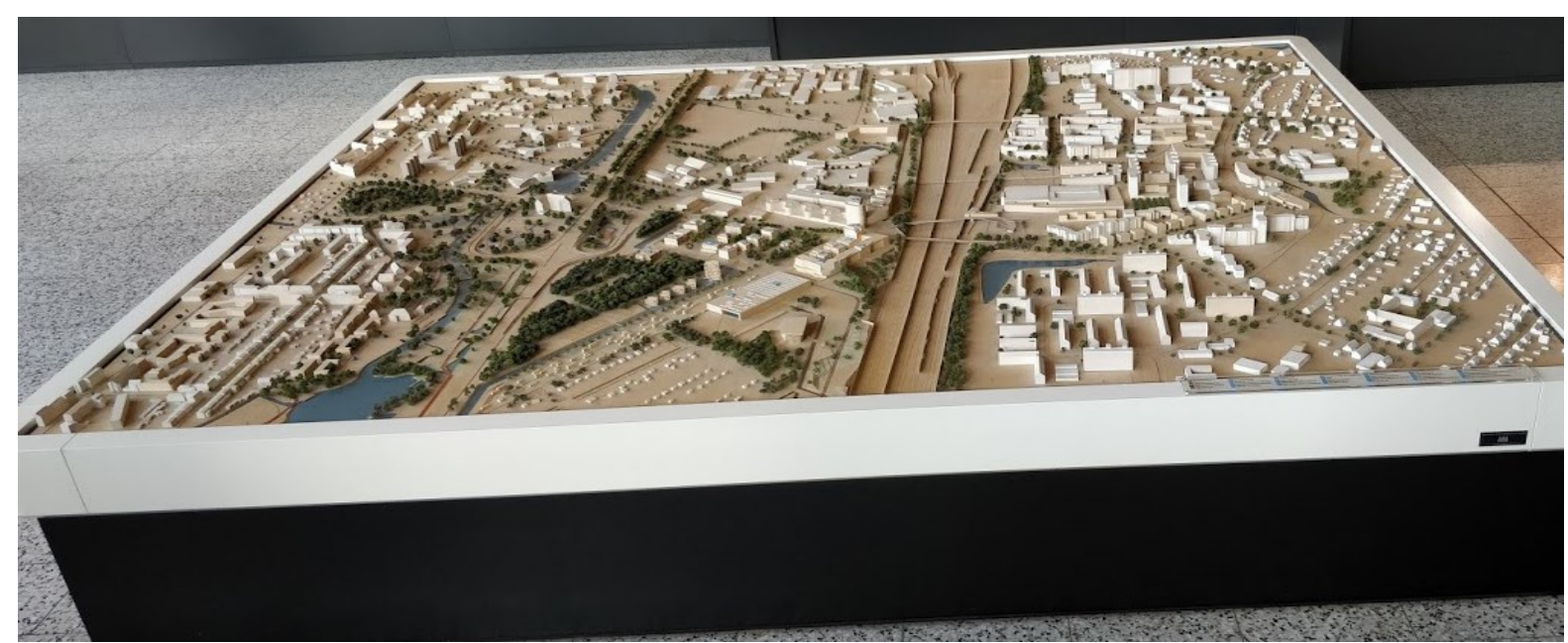

Resim 11: Wilhelmsburg proje alanı (yazarın kendi arşivi, Şubat 2020). 
2006 yılında başlayan dönüşüm çalışmalarının amacı; bu alanda birlikte yaşayan insanların kente aidiyet duygusunu geliştirmek, bölgeye yeni bir kimlik kazandırmak, nitelikli kentsel alanlar yaratmak ve sürdürülebilir bir kent konsepti oluşturup halkın yaşam kalitesini artırmak olarak belirlenmiştir (Avlar \& Y1lmaz, 2018: 109).

IBA 2006 yılında ilk etapta çalışmalara, 70 bina projesi ve 14 sosyal kültürel proje ile başlamıştır. Bu

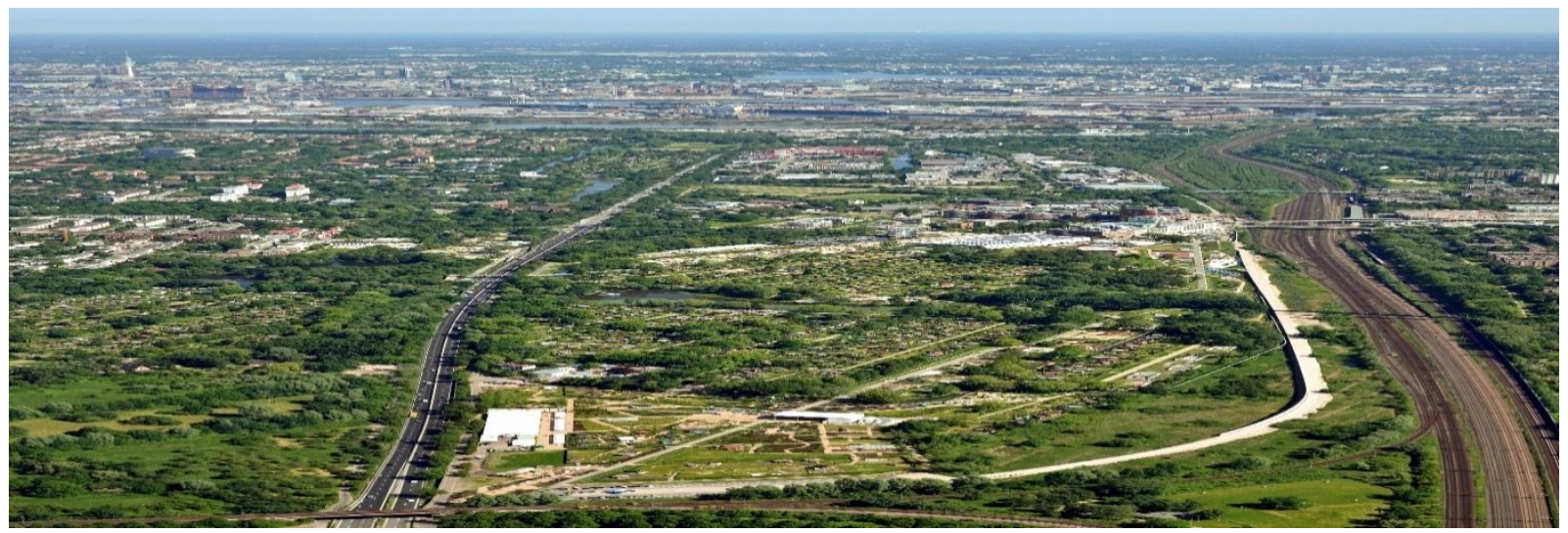

Resim 12: Dönüşüm alanı ve önünde Hafencity (https://www.internationale-bauausstellunghamburg.de/fileadmin/Mediathek/Pressebilder/Aktualisierung_1701/DSC_2369_Originale_.jpg)

projeler modern, çevre ve iklim dostu bir şehir planlamasının geleceğini gösterme vizyonuyla hareket etmekteydi (Hellweg, 2018: 120). Bölgenin enerjisi tüketicilere yetecek oranda kendi bölgesinde üretilmektedir. 2. Dünya Savaşı'nda binlerce insanın sığınak olarak kullandığı Energy Bunker binasının çatı ve güney cephesine güneş panelleri yerleştirilmiş ve üretilen bu enerjiyi depolamak adına termal depolama sistemi kurulmuştur (Avlar \& Y1lmaz, 2018: 109). Bugün bu bina 3.000 haneye 1sıtma ve 1.100 eve elektrik sağlamaktadır.

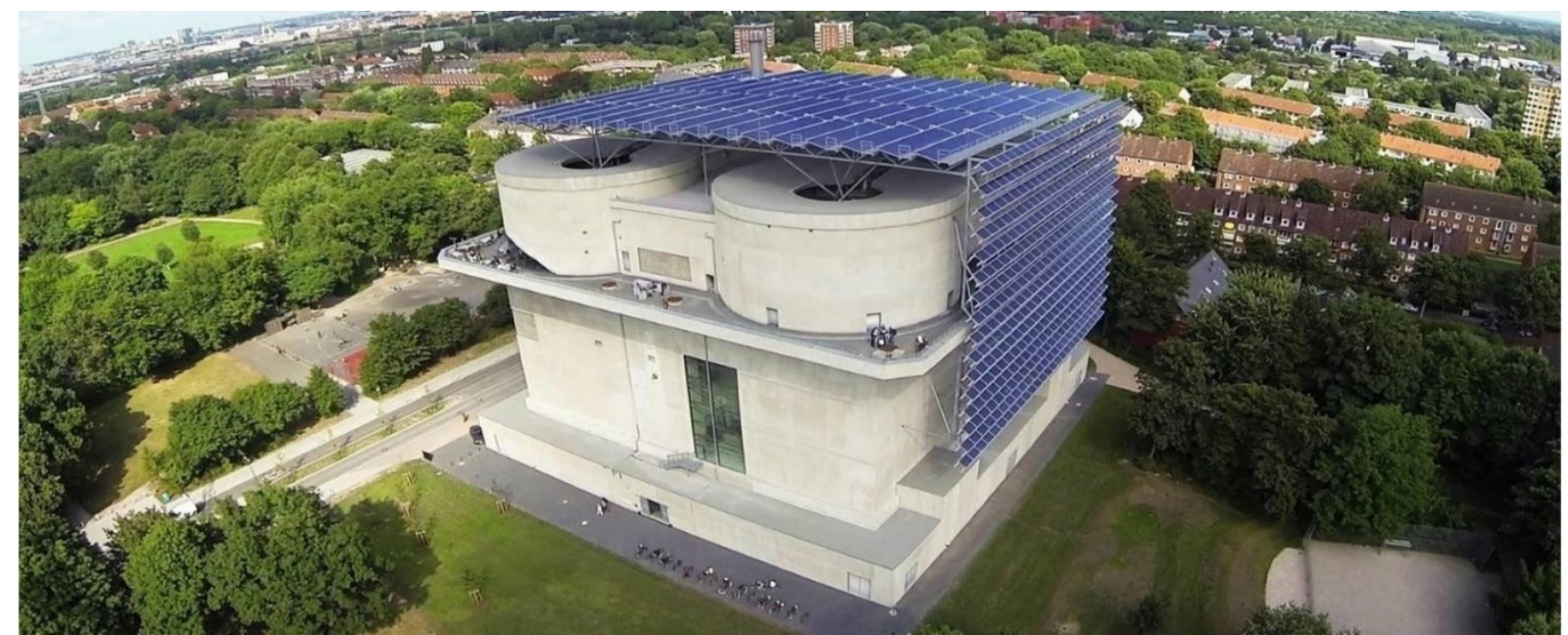

Resim 13: Energie Bunker binasl (https://www.welt.de/regionales/hamburg/article194210695/Geothermie-

Hamburg-setzt-auf-Waerme-aus-der-Tiefe.html\#cs-Energiebunker-Wilhelmsburg-Hamburg-Ener.jpg) 
Ayrıca bölgede inşa edilen yarım düzine yüksek verimli akıllı ev teknolojisiyle, üretilen fazla elektrik de merkezi olmayan şebekeleri beslemektedir.

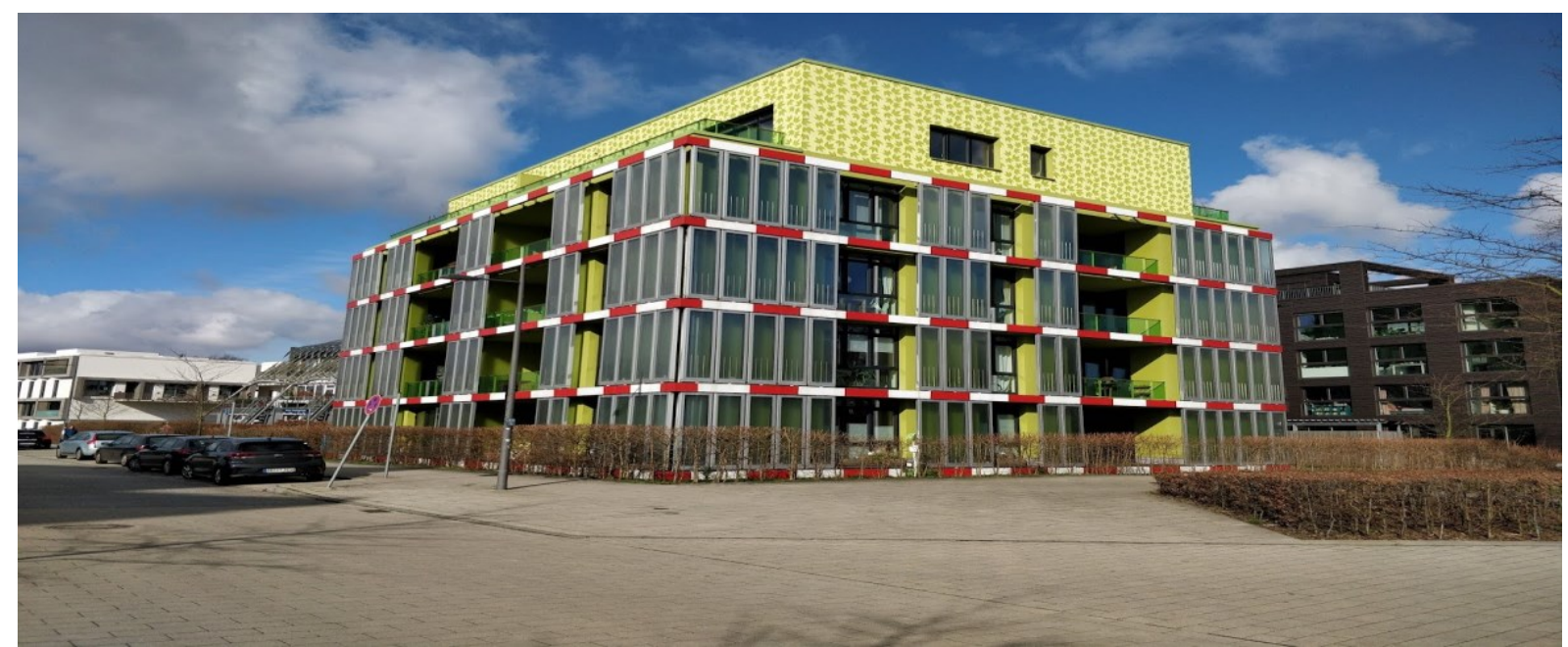

Resim 14: Kendi enerjisini üretebilen akıllı evler (yazarın kendi arşivi, Şubat 2020)

Buna ek olarak 1980'lere kadar atık depolama alanı olarak kullanılan Enerji Tepesi'ne 2013 yılında kurulmuş olan rüzgar tribünüyle yaklaşık 4.000 haneye enerji sağlanmaktadır (Hellweg, 2018: 121).

Resim 15: Enerji Tepesi (yazarın kendi arşivi, Şubat 2020)

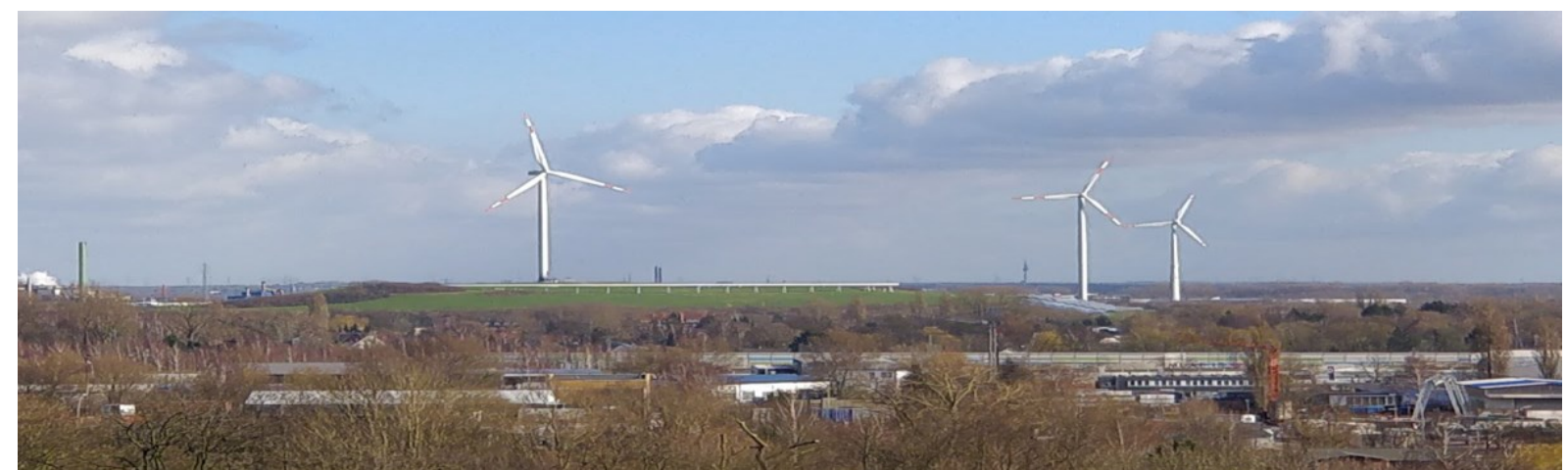

"Kaldığın yer evindir" sloganıyla bölgede sosyal ve kültürel gelişmeler için firsatlar aranmıştır.

Bölgedeki etnik ve kültürel farklılıkların bir güç haline dönüştürülmesine çalışılmış, eğitimde yeni öğrenme yaklaşımları, yeni ve farklı türden eğitim tesislerinin kurulması desteklenmiştir.

Final yılı olarak kabul edilen 2013 yılına gelindiğinde, 516'sı yenilenmiş daire olmak üzere toplam 1.733 konut birimi yapılmıştır. Ayrıca 100.000 metrekare ticari alan, sekiz eğitim kurumu, iki yaşlılar evi, üç kreş, dört spor tesisi, bir ticaret parkı, sanatçılar ve yaratıcı işçiler için bir merkez ve 70 hektar yeşil alan oluşturulmuştur (IBA Hamburg, 2019).

Neredeyse bir yüzyıl boyunca Wilhelmsburg yaşanacak bir yer olarak görülmedi. Hamburg kent merkezine yakın olmasına rağmen, kentin en gürültülü ve en kirli işlevlerinin gözden gizlenerek yapıldığı bir yer olarak kabul edildi. Şehir plancıları burayı yerel tersanelerde fabrikalarda ve demiryollarında çalışan insanları barındırmak dışında konut gelişimi için uygun bir yer olarak görmediler. IBA ise, sorunlu olarak görülen bir mahalleyi karma kullanımlı bir alanla kente entegre edip, yeni orta sınıf sakinleri için alan yaratmayı amaçlamıştır. Özellikle genç aileleri bölgeye çekmek 
için kreşler, okullar ve spor merkezleri yapıldı. Bugün Wilhelmsburg'taki sakinlerin dörtte biri 25 yaşın altındadır (Chamberlain, 2020).

Kentsel dönüşüm teorilerinden yeniden geliştirmenin (redevelopment) uygulandığ bölgede; kentin geçmişle ilgili referanslarından kurtulmak ve yaşam alanlarını kapsamlı olarak sağlıklaştırmak amaçlı büyük ölçüde yıkımlar ve yeniden yapılanmalar gerekmiştir. Bu hamleler yapılırken de bölgede yerel ve yenilenebilir kaynaklara odaklanarak tüm bir bölgeyi yenilenebilir bir şekilde yeniden geliştirmek amaçlanmıştır.

Tablo 3: Sayılarla Wilhelmsburg Projesi

\begin{tabular}{|l|l|}
\hline \multicolumn{2}{|c|}{ Sayılarla Wilhelmsburg Projesi } \\
\hline Slogan & "Kaldığın yer evindir" \\
\hline Alanın toplam büyüklüğü & $35.3 \mathrm{~km}^{2}$ \\
\hline Konut sayısı & 1733 konut (516's1 yenileme) \\
\hline Belediye binasına uzaklık & $8 \mathrm{~km}$ \\
\hline Merkez tren garına uzaklık & $7,5 \mathrm{~km}$ \\
\hline Havaalanına uzaklık & $17 \mathrm{~km}$ \\
\hline Ulaşım & $\begin{array}{l}\text { Kent merkezine ve otoyollara bağlantıları olan } \\
\text { verimli yol ağı ve toplu taşıma sistemi }\end{array}$ \\
\hline Nüfus & 55074 \\
\hline Bütçe & 1 milyar Euro (2/3 özel sektör) \\
\hline Süreç & 2013 yılında ana proje tamamlandı \\
\hline
\end{tabular}

\section{Sonuç}

Avrupa'nın yıllar boyu en önde gelen liman kentlerinden olan Hamburg'un en önemli ve ekonomik olarak hayati rolü olan liman ve depolama alanı, 1980'ler sonrası hem kent merkezinin genişlemesi hem de hizmet sektörünün ön plana çıkmasıyla terkedilmeye ve kullanımı değişmeye başlamıştı. Liman işçilerinin konaklamayı tercih ettiği bölge mahallelerinden olan Wilhelmsburg ise, işçi sınıfının işlerini kaybetmesi, bölgede yaşanan sel felaketi gibi nedenlerle köhneleşme sürecine girmişti. Değeri düşen alan, bir göçmen ve sorun mahallesi haline gelmiş, terkedilmiş ve atıl bir alana dönüşmüştü.

Bir sermaye birikim aracına dönüşen kentsel mekanın değerlendirilmesi ve yeniden üretilmesi kapsamında bu alanların dönüşümü söz konusu olmuş, hatta Wilhelmsburg’taki sakinler daha nitelikli bina, okul ve sosyal alanlar talep etmiştir. Ayrıca bu talepler sadece insan odaklı değil aynı zamanda çevresel değerleri de ön planda tutan yaklaşımlarla karşılık bulmuştur. 
İncelenen iki dönüşüm projesi karşılaştırıldığında dönüşümlerinde birbiriyle örtüşen noktalar bulunmakla birlikte birkaç yönüyle de birbirinden ayrılmaktadır. Hafencity bölgesi gelişen teknoloji ile kendiliğinden kullanım dışı kalmış ve çöküntü alanına dönüşmüş bir bölgeydi. Eski liman alanı için üretilen projede alanın tarihsel mirası ve kimliğinin korunması amacıyla bazı yapıların ve kimliksel öğelerin (eski raylar, limanın tarihi duvarları ve işlemeleri ile depolama alanları gibi) alanda korunduğu görülmektedir. Karma bir kullanım için tasarlanan alanın büyük bir bölümünün mülkiyetinin kamuda olması da dönüşüm sürecine kolaylık sağlamış ve bu parsellerin satışıyla projeye finansman sağlanmıştır. Belirli bir master plan çerçevesinde ilerleyen projede, her ne kadar değişiklikler yapılsa da ana plana sadık kalınmıştır. Sonuç olarak katılım boyutunda eleştiriler alan projenin yine de başarılı bir proje olduğunu söyleyebiliriz.

Wilhelmsburg projesi ise Hafencity'nin talep ettiğinden farklı bir amaç talep etmektedir. Bölge sakinlerinin direk katılımı ve istekleriyle başlayan süreç, bölgede daha çok sosyal ve kültürel gelişimlerin sağlanmasını hedefliyordu. Bu hedeflere ek sürdürülebilirlik kapsamında yenilenebilir enerji konsepti de eklenmiştir. "Kaldığın yer evindir" temasıyla hareket eden proje, sakinlerin yerlerinden edilmeden sürece dahil edilmelerini amaçlamış, kentsel uyumu ve aidiyeti arttırmayı temel hedef belirlemiştir. Fakat diğer taraftan bölgede bir "sosyal karışım (social mixing)" amaçlanmış ve göçmen mahallesi olarak anılan mahallenin merkezindeki dönüşüme uğramış yüksek maliyetli konutlara (hatta akıllı ev olarak tasarlanan konutlar) eğitimli orta sınıfın taşınması planlanmıştır. Zaten kiracı konumunda olanlar yine de mahalleden çok uzaklaşmamış, mahallenin çeperine taşınmıştır. Wilhelmsburg sakinlerinin talep ettikleri sosyal refah, kendilerine bölgenin soylulaştırılması olarak geri dönmüştür.

Bu çalışma kapsamında Hamburg'da farklı alanlarda farklı temalarla fakat aynı vizyon içerisinde nasıl bir kentsel değişim ve dönüşüm modeli geliştirdiği incelenmiştir. Uygulanan bu kentsel dönüşüm modellerinde ortak noktalar ise hem çevreyi hem de kent yaşamını koruyabilen ayrıca gelecek kuşaklara da aktarılabilen kentsel alanlar yaratılmasıdır. Sürdürülebilirlik özellikle ekolojik açıdan belirleyici bir faktör olmuştur. İki projede de karma kullanım hedeflenmiştir. Alanın canlılığını arttırmak ve gecegündüz kullanımını dengelemek amacıyla karma kullanım desteklenmiştir. Bir zamanlar kötü imajlara sahip olan bu alanlar ana ulaşım hatlarına eklenerek kent merkezine entegre edilip, daha fazla konut, ofis, mağaza ve aktivite alanı yaratmak için yeniden canlandırılmış ve yapılandırılmıştır.

Çalışma kapsamında Hamburg'da yerinde incelenen örneklerde de yer alan IBA gibi kamu destekli kurum veya kuruluşlar yerel yönetimler adına kentsel dönüşüm süreçlerinde aktif rol almakta, planlamadan finansman sağlamaya kadar pek çok konunun sağlıklı olarak gerçekleşmesi için kullanıcılar ve uzmanlarla birlikte alan üzerinde karar verme süreçlerini yönetmektedirler. Kamu destekli kuruluşların koordine ettiği gerek yerel gerek merkezi yönetimler tarafindan denetlenen, katılımın yüksek olduğu ve ulusal/uluslararası fonların da desteğiyle kentler, dönüşüm süreçlerinde olabildiğince az sorunla karşılaşıp, sürecin daha başarılı ve sağlıklı gerçekleşmesine sahne olacaklardır. 


\section{Kaynakça}

Akyol, İ. (2010). Kent İ̧̧erisinde Kullanım Dışı Kalmakta Olan Endüstriyel Alanlarda Kentsel Dönüşüm: Kartal Kentsel Dönüşüm Projesi ve Hamburg Hafencity Örneği, Yayımlanmamış Yüksek Lisans Tezi Mimar Sinan Güzel Sanatlar Üniversitesi.

Avlar, E., \& Yılmaz, S. (Eds.) (2018). Kentsel Dönüşüm Uygulamasında Örnek Bİr Proje: IBA Hamburg. Türk Mühendis ve Mimar Odaları Birliği: Türk Mühendis ve Mimar Odaları Birliği.

Bruns-Berentelg, J. (Ed.) (2006). Hafencity Hamburg Der Masterplan (2. Bask1). Hamburg: Ministry of Urban Development.: Ministry of Urban Development.

Bruns-Berentelg, J. (2014). HafenCity Discussion Paper No: 3.: Identity, Sustainability and Urbanity. Hamburg.

Chamberlain, J. (2020). Experimenting on Racialized Neighbourhoods: Internationale Bauausstellung Hamburg and the urban laboratory in Hamburg-Wilhelmsburg. EPD: Society and Space, 1-19. https://doi.org/10.1177/0263775820903328

Deutschlandfunk Kultur (2010). - Wir wollen unsere Stadt zurück! Retrieved from https://www.deutschlandfunkkultur.de/wir-wollen-unsere-stadtzurueck.1063.de.html?dram:article_id=175319

Eraslan, İ. G. (2007). Yönetim Mekanizmalarının Kentsel Dönüşüm Algısı ve Uygulamaları Üzerindeki Etkisi:: Ingiltere, Almanya ve Türkiye Örnekleri. Yıldız Teknik Üniversitesi, İstanbul.

Hansing, A. (2017). Bulding The City Anew. Hamburg.

Hellweg, U. (2018). Renewable Wilhelmsburg, Hamburg, Germany:: Using the International Building Exhibition to Fight Climate Change. In Urban Energy Transition (pp. 115-129). Elsevier. https://doi.org/10.1016/B9780-08-102074-6.00019-X

IBA Hamburg (2019, July 16). Retrieved from https://www.internationale-bauausstellunghamburg.de/en/story/iba-hamburg.html

IBA Hamburg. Retrieved from https://www.internationale-bauausstellung-hamburg.de/en/story/iba-hamburg.html Karadağ, D. (2008). Kentsel Dönüşüm Yöntemleri, Arkitera.

Kayıkçı, S. (2003). Federal Almanya Cumhuriyeti'nde Mekan Planlama Sistemi. Planlama Dergi, 26.

Köktürk, E. [Erol], \& Köktürk, E. [Erdal] (Eds.) (2007). Türkiye'de Kentsel Dönüşüm ve Almanya Deneyimi.

Reicher, C. (2005). Urban Planning and Design In Germany: Recycling The Town and The Region. Planlama Dergi, 3, 56-64.

Strubelt, W., Gatzweiler, H.-P., \& Kaltenbrunner, R. (2000). Urban Development and Urban Policy in Germany: An Overview. Bonn.

WELT (2009, August 23). Protest: 200 Künstler besetzen Häuser im Gängeviertel. WELT. Retrieved from https://www.welt.de/regionales/hamburg/article4383541/200-Kuenstler-besetzen-Haeuser-imGaengeviertel.html 